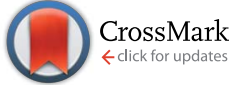

Cite this: RSC Adv., 2016, 6, 105878

\title{
p-Bromoaryl- and $\omega$-bromoalkyl-VA-PNBs: suitable starting materials for the functionalization of vinylic addition polynorbornenes via palladium- catalyzed cross-coupling reactions $\uparrow$
}

\author{
Sheila Martínez-Arranz, Eduardo Sánchez-Pérez, Jesús A. Molina de la Torre, \\ Ignacio Pérez-Ortega and Ana C. Albéniz*
}

\begin{abstract}
New vinylic addition polynorbornenes (VA-PNBs) with a variable amount of pendant 4-bromoaryl groups have been synthesized by homo- and copolymerization with norbornene of 2-(4-bromophenyl)-5norbornene catalyzed by $\left[\mathrm{Ni}\left(\mathrm{C}_{6} \mathrm{~F}_{5}\right)_{2}\left(\mathrm{SbPh}_{3}\right)_{2}\right]$. These polymers can be transformed by $\mathrm{Pd}$-catalyzed cross coupling reactions into VA-PNBs with pendant diaryl (Suzuki), alkenyl and ketoalkyl (Stille) and amino (Buchwald-Hartwig) groups. Although the cross-coupling reactions of alkylhalides are more difficult, ( $\omega$ bromobutyl)-VA-PNBs can also be functionalized by a Suzuki reaction with arylboronic acids. This results open up new ways of post-polymerization functionalization of VA-PNBs, quite attractive for their robust, thermally stable and transparent skeleton.
\end{abstract}

Received 16th September 2016 Accepted 30th October 2016

DOI: $10.1039 / \mathrm{c} 6 \mathrm{ra23123c}$

www.rsc.org/advances

polar groups notably decreases the reactivity of norbornenes towards double bond insertion polymerization (VApolymerization) and most catalyst that are very active for the VA-polymerization of norbornene do not perform well with substituted norbornenes. Only a few nickel or palladium catalysts can polymerize substituted norbornenes (NB-R) or copolymerize them with norbornene to give VA-PNBs., ${ }^{2,3 a, 4,8,9}$ Additionally, since the NB-R are usually synthesized by a DielsAlder reaction, they are a mixture of exo and endo isomers which have different polymerization rates and this is sometimes an extra difficulty. ${ }^{10}$ We reported a different strategy to synthesize functionalized VA-PNBs that circumvents this problem and involves the post-polymerization functionalization of a VA-PNB with pendant $\omega$-bromoalkyl units. ${ }^{8}$ The bromoalkyl-polymer can be obtained in good yields and different bromo loadings by direct copolymerization of $\mathrm{NB}$ and $\mathrm{NB}-\left(\mathrm{CH}_{2}\right)_{n} \mathrm{Br}$ using $\left[\mathrm{Ni}\left(\mathrm{C}_{6}-\right.\right.$ $\left.\left.\mathrm{F}_{5}\right)_{2}\left(\mathrm{SbPh}_{3}\right)_{2}\right]$. The nucleophilic substitution of bromide in the polymer leads to VA-PNBs with polar groups (ester, cyano, SR, imidazole, etc.), ${ }^{\mathbf{8} 5 \boldsymbol{b}}$ as well as the azido moiety that can be used as to anchor other groups by a click CuAAC reaction with alkynes. $^{5 c}$ The versatility of these brominated VA-PNBs led us to

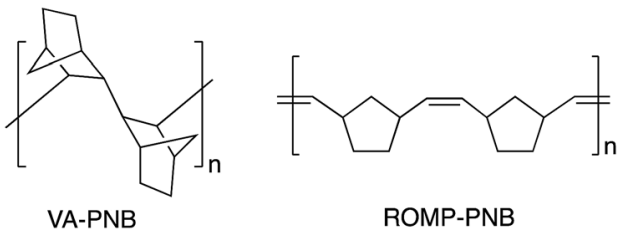

Fig. 1 Types of polynorbornene backbone. 
explore the possibility of using Pd-catalyzed cross coupling reactions to functionalize VA-PNBs. For that, we envisioned that a VA-PNB with pendant bromoaryl groups would be a suitable parent material. Thus, we describe here the preparation of those polymers as well as the application of a variety of Pd-catalyzed cross coupling reactions to give VA-PNBs with pendant biaryls, anilines and other groups. The functionalization of the more challenging VA-PNBs with $\omega$-bromoalkyl groups by the same methods is also reported.

Cross-coupling reactions catalyzed by palladium are extremely useful in synthesis and this has been highly recognized. ${ }^{11}$ In the realm of polymer chemistry these reactions have found application in the synthesis of polymeric materials by condensation of two doubly-functionalized coupling reagents. It is worth mentioning the Stille reaction for the preparation of a variety of polymers, ${ }^{12}$ the Suzuki and Sonogashira couplings in the synthesis of polyfluorenes, ${ }^{\mathbf{1 3}}$ and some examples that involve the Heck reaction, ${ }^{\mathbf{1 4}}$ the Buchwald-Hartwig amination, ${ }^{\mathbf{1 5}}$ or the related ipso-arylation. ${ }^{\mathbf{1 6}}$ Fewer examples can be found of the application of $\mathrm{Pd}$-catalyzed $\mathrm{C}-\mathrm{C}$ or $\mathrm{C}-\mathrm{X}$ bond forming reactions for the post-polymerization functionalization of preformed polymers. ${ }^{17}$ Most examples report the use of the Sonogashira coupling to synthesize derivatives of polystyrene, ${ }^{18}$ or polyphenylene. ${ }^{19}$ Polytriazoles, ${ }^{20}$ and polythiophenes have also been subjected to this type of reactions. ${ }^{21}$ The functionalization of polymers by palladium-catalyzed $\mathrm{C}-\mathrm{N}$ bond formation has been scarcely used on polystyrene, ${ }^{22}$ or PEG. $^{23}$

\section{Results and discussion}

\section{Synthesis of $p$-bromoaryl VA-PNBs}

Polymers with pendant bromoaryl groups were synthesized by homopolymerization of $\mathbf{1}$ or co-polymerization of this monomer with norbornene (NB) (Scheme 1). Monomer 1 is not commercial and it was synthesized by a Diels-Alder reaction of 1-bromo4 -vinylbenzene with cyclopentadiene. In order to avoid radical side reactions 2,6-ditertbutylphenol was used as a trap. 1 is a mixture of isomers in a ratio endo : exo $=80: 20$ and this mixture was used for the polymerization reactions.

The polymerization reactions were carried out as shown in Scheme 1 and the results are collected in Table 1 . $\left[\mathrm{Ni}\left(\mathrm{C}_{6} \mathrm{~F}_{5}\right)_{2}\right.$ $\left.\left(\mathrm{SbPh}_{3}\right)_{2}\right]$ was chosen as catalyst because of its high activity both

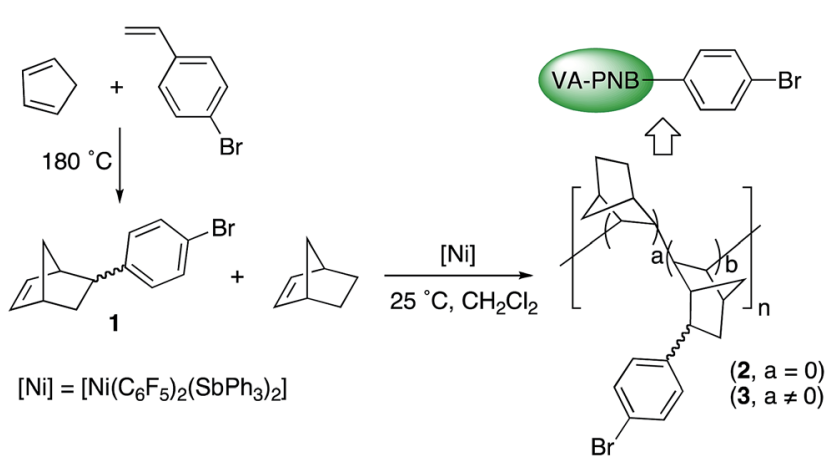

Scheme 1 Synthesis and polymerization of 1 to give $p$-bromophenylVA-PNBs. in homopolymerization of norbornene and in the copolymerization of norbornene with substituted norbornenes with $\omega$ haloalkyl or alkyltin groups..$^{\mathbf{f d}, \mathbf{8 , 2 4}}$ It is also very easy to handle as it is stable to moisture and air. The concentration of $\mathbf{1}$ was the same in all the experiments and the amount of NB in the copolymerization reactions was varied to reach the required monomer feed ratio; a catalyst loading between 0.5 and $2 \mathrm{~mol} \%$ was used depending on the experiment (it is referred to the total amount of monomer). Monomer 1 can be homopolymerized with this catalyst with a moderate yield to give polymer 2 (entry 1, Table 1). The copolymerization of NB and 1 gave polymers 3 with different composition depending on the monomer feed ratio $(a / b=\mathrm{NB} / \mathbf{1}$ ratio in the polymer, Scheme 1$)$, and moderate to good yields, the better the higher the NB ratio in the feed mixture. All the polymers are obtained by precipitation in $\mathrm{MeOH}$ as off-white solids. The ratio $a / b$ was determined by quantitative analysis of the Br content in the polymer.

The polymers synthesized showed unimodal distributions in GPC and a polydispersity in the range of 2.3-3.9. The molecular weight range was between $8 \times 10^{3}$ to $120 \times 10^{3} \mathrm{Da}$ and it increased as the ratio of NB increased. When the ratio NB : 1 in the feed was higher than those shown in Table 1, insoluble polymers were obtained that could not be characterized by GPC.

According to the data in Table 1 (entries 2-6), a rough determination of the reactivity ratios of $\mathrm{NB}$ and $\mathbf{1}$ can be made: $r_{\mathrm{NB}}=1.86$, and $r_{1}=0.45 .^{25}$ These values imply that NB has a higher probability than 1 of entering the copolymer, so the composition of copolymers 3 obtained do not reproduce the monomer feed ratio and are always richer in NB. A composition drift of the copolymer as the polymerization proceeds is also expected.

Polymers 2 and 3 were characterized by IR, ${ }^{1} \mathrm{H}$ and ${ }^{13} \mathrm{C}$ NMR. The NMR spectra in solution showed broad signals corresponding to the NB skeleton. The aromatic signals of the pendant bromoaryl groups were clearly observed in the ${ }^{1} \mathrm{H}$ and ${ }^{13} \mathrm{C}\left\{{ }^{1} \mathrm{H}\right\}$ NMR spectra. No signals around $20 \mathrm{ppm}$ were observed in the ${ }^{13} \mathrm{C}$ NMR, which indicated exo-enchained norbornene units in the polymer backbone. ${ }^{26}$ Furthermore, in these polymers terminal pentafluorophenyl groups were observed in the ${ }^{19}$ F NMR spectra, which suggest an insertion polymerization mechanism with an initiation step that involves insertion of the olefin in the $\mathrm{Ni}-\mathrm{C}_{6} \mathrm{~F}_{5}$ bond. ${ }^{\mathbf{8 , 2 4 , 2 7}}$ The IR spectra of polymers 2 and 3 clearly show a band at $1075 \mathrm{~cm}^{-1}$ due to the $\mathrm{C}^{\mathrm{Ar}}-\mathrm{Br}$ stretching. After obtaining the polymers, the analysis by ${ }^{1} \mathrm{H}$ NMR of the mother liquors showed that in all the cases the unreacted endo-1 : exo-1 ratio showed values in the range 100:0 to $91: 9$, higher than the endo-1 : exo-1 $=80: 20$ ratio in the initial monomer. This clearly shows that, as expected, the exo isomer of 1 reacts preferently to the endo isomer in transition metal NB-insertion polymerization.

\section{Functionalization of $\boldsymbol{p}$-bromoaryl VA-PNBs}

A simplified mechanism for palladium-catalyzed cross coupling reactions involves three main steps: oxidative addition of the organic halide, coordination of the nucleophilic reagent, by transmetalation in most cases, and reductive elimination 
Table 1 Homo and copolymerization reactions of 1 and norbornene to give polymers 2 and $3^{a}$

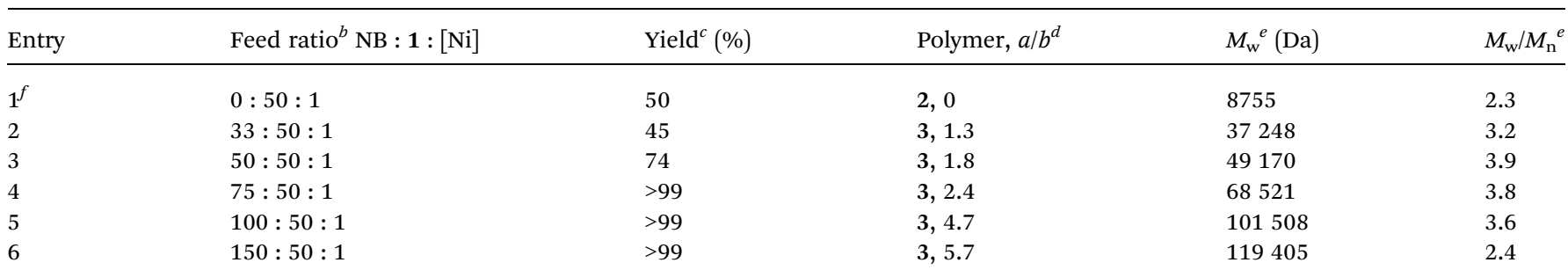

${ }^{a}$ The reactions were carried out using $\mathrm{CH}_{2} \mathrm{Cl}_{2}$ as solvent, $0.4 \mathrm{mmol}$ of $\mathbf{1}$ and a total volume of $9 \mathrm{~mL}$ (unless otherwise noted) at room temperature for 10 min. ${ }^{b}$ Molar ratio in the feed. ${ }^{c}$ Yields are referred to the total monomer mass. ${ }^{d} a / b=\mathrm{NB} / \mathrm{NBC}_{6} \mathrm{H}_{4} \mathrm{X}$ molar ratio; it was determined by quantitative analyses of the bromine in the polymer. ${ }^{e}$ Determined by GPC using polystyrene standards. ${ }^{f} 0.80 \mathrm{mmol}$ of 1 were used and a total volume of $18 \mathrm{~mL}$; reaction time $24 \mathrm{~h}$.

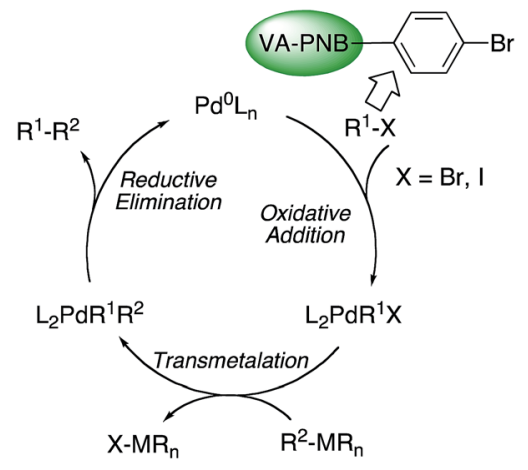

Scheme 2 Simplified catalytic cycle for Pd-catalyzed cross-coupling reactions.

(Scheme 2).$^{28}$ The actual mechanism in each case may involve additional isomerizations, ligand coordination and exchange reactions, which are also important, but the representation in Scheme 2 can be used as a reasonable working guide. VA-PNBs 2 and 3 , the organic halide reagents, should undergo oxidative addition to palladium, the first step in Scheme 2, if they are to be functionalized by these reactions. In order to test this point the reaction of 3 and $\left[\mathrm{Pd}\left(\mathrm{PPh}_{3}\right)_{4}\right]$ was carried out (eqn (1)). Indeed the reaction occurred and a palladium-functionalized polymer, 4, was obtained. IR analysis showed the disappearance of the $\nu\left(\mathrm{C}^{\mathrm{Ar}}-\mathrm{Br}\right)$ at $1075 \mathrm{~cm}^{-1}$ band and the appearance of the bands corresponding to the $\nu(\mathrm{Pd}-\mathrm{P})$ at $539 \mathrm{~cm}^{-1}$. The formation of 4 also becomes clear when we recorded ${ }^{13} \mathrm{C} \mathrm{CP}$ MAS and ${ }^{31} \mathrm{P}$ CP-MAS spectra, where a signal at $26 \mathrm{ppm}$ typical of a coordinated $\mathrm{PPh}_{3}$ to palladium in a trans " $\mathrm{PdP}_{2}$ " arrangement, is observed.

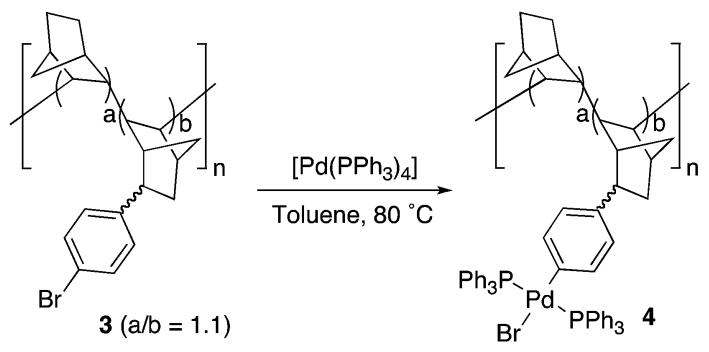

Once we found out that polymer 3 is a suitable reagent for the coupling processes, we tested the utility of the Suzuki reaction to introduce aryl groups on $\mathbf{3}$. Scheme 3 (top) collects the aryl groups introduced and Table 2 the reactions tried. Polymers 5-8 were obtained in good yields (82-98\%) as greyish solids insoluble in common organic solvents.\$ Thus, they were characterized by IR and solid state MAS-NMR, and the most significant absorptions of each group are clearly visible with both techniques (see the Experimental section and ESI $\dagger$ ). The extent of the reaction was measured by quantitative analyses of the residual bromine in the polymer products, and it is given as the percentage of $\mathrm{Br}$ that has been substituted in Table 2. Two different sets of reaction conditions were employed. Method A (entries 1-6, Table 2) uses the best reaction conditions we found using palladium catalysts with conventional aryl phosphines (see $\mathrm{ESI} \dagger$ for additional optimization experiments). Using $\left[\mathrm{PdCl}_{2}(\mathrm{dppf})\right]$ as precatalyst in toluene at $110{ }^{\circ} \mathrm{C}$ good results were obtained for the boronic acids $\operatorname{BAr}(\mathrm{OH})_{2}$ where $\mathrm{Ar}=\mathrm{Ph}, 4$ $\mathrm{CF}_{3}-\mathrm{C}_{6} \mathrm{H}_{4}$ (entries 1-4, Table 2). The reaction works well regardless the composition of the starting polymer 3 , so polymers with different degree of functionalization can be obtained (entries 2-4, Table 2). Method A is less efficient for $\mathrm{Ar}=4-\mathrm{OMe}-$ $\mathrm{C}_{6} \mathrm{H}_{4}, 2-\mathrm{Me}-4 \mathrm{OMe}-\mathrm{C}_{6} \mathrm{H}_{3}$ (62\% of Br substituted, entries 5, 6, Table 2). However, the reaction conditions of Method B, used by Fu et al. for more challenging alkyl halide substrates, proved to be superior (see below). In the presence of the precatalyst system $\left[\mathrm{Pd}_{2}(\mathrm{dba})_{3}\right] / \mathrm{P}^{t} \mathrm{Bu}_{2} \mathrm{Me}$ and 2-methyl-2-butanol as solvent, almost complete reaction of the arylbromo substituents of the polymer was achieved (entries 7, 8, Table 2).

\footnotetext{
$\$$ After functionalization, all the polymers synthesized in this work are not soluble in most common organic solvents. We could not determine the exact reason of this change in properties. There is no loss of bromine when the homopolymer 2 was subjected to prolonged heating $(48 \mathrm{~h})$ in toluene or 2-methyl-2-butanol at $T$ $=100-110{ }^{\circ} \mathrm{C}$, indicating that no cross-linking derived from unwanted reactions of this group alone takes place. It has been shown that the rigid nature of the VA-PNB skeleton leads to polymers in metastable conformations that can rearrange upon heating and produce a change of properties (see ref. $5 f$ and $\mathrm{P}$. P. Chu, W.-J. Huang, F.-C. Chang, S. Y. Fan, Polymer 2000, 41, 401-404). This could have some importance along with the introduction of an additional rigid aromatic group that alters the morphology of the material and consequently its response to solvation. The occurrence of a small amount of homocoupling in the bromoaryl derivatives 3 (less likely in the bromoalkyl PNBs 16) may also contribute to the change in solubility and cannot be ruled out.
} 


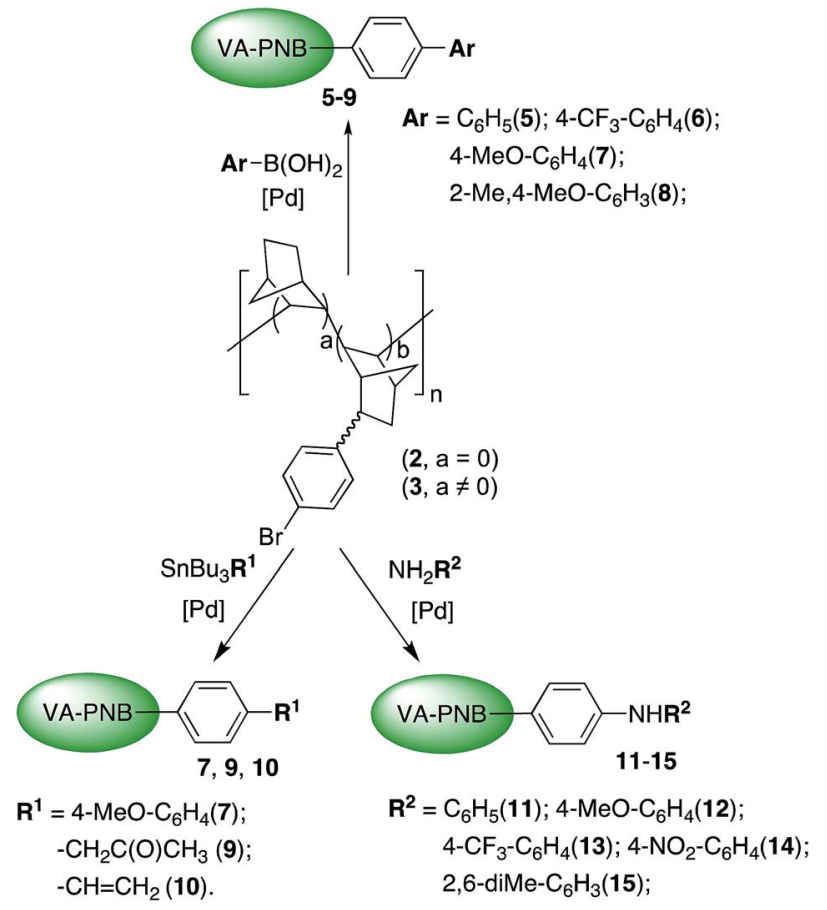

Scheme 3 Functionalization of VA-PNBs 2 and 3 by Pd-catalyzed $\mathrm{C}-\mathrm{C}$ and $\mathrm{C}-\mathrm{N}$ coupling.

The Suzuki reaction is the most convenient one for the formation of a pendant biaryl moiety on the polymer. The Stille reaction is a viable but less efficient alternative for this type of groups as shown in entry 3, Table 3. However the use of $\mathrm{SnBu}_{3} \mathrm{R}$ $(\mathrm{R} \neq \operatorname{aryl})$ leads to VA-PNBs functionalized with ketoalkyl (9) or vinyl (10) groups in a very good or moderate $\mathrm{Br}$ substitution degree respectively (entries 1 and 2, Table 3). In the case of $\mathbf{9}$, the required organostannane can be easily prepared in situ from $\mathrm{SnBu}_{3} \mathrm{OMe}$ and 2-propenylacetate. Both $\mathbf{9}$ and $\mathbf{1 0}$ are insoluble in common solvents and, again, their characterization was made by IR and solid state MAS-NMR (see Experimental section).

The Buchwald-Hartwig amination reaction is a good route for the formation of supported diaryl amines on VA-PNBs. The reaction of 3 in the presence of different anilines, a base and a mixture of $\left[\mathrm{Pd}_{2} \mathrm{dba}_{3}\right]$ and X-Phos as precatalyst led to polymers 11-15 with complete bromo-substitution (Scheme 3 and Table 4). The reaction conditions followed those reported by Marqués et al. for the synthesis of PEG derivatives with pendant anilines. ${ }^{23}$ Amines with either electron-donating or electronwithdrawing groups on the aryl ring can be introduced (entries 1-4, Table 4). An increase in the steric bulk of the aniline is not a problem either (entry 5 , Table 4 ). The IR spectra of polymers 11-15 clearly shows the disappearance of the $\nu\left(\mathrm{C}^{\mathrm{Ar}}\right.$ $\mathrm{Br}$ ) at $1075 \mathrm{~cm}^{-1}$ and a new weak resonance at about $3400 \mathrm{~cm}^{-1}$ typical of the $\mathrm{N}-\mathrm{H}$ stretching.

\section{Functionalization of $\omega$-bromobutyl VA-PNB}

A more challenging reaction is the functionalization of bromoalkyl VA-PNBs by Pd-catalyzed C-C cross coupling reactions. After oxidative addition of an alkylhalide $\left(\mathrm{R}^{1}=\right.$ alkyl, Scheme 2$)$, the transmetalation step competes with a favorable $\beta-\mathrm{H}$ elimination that often hampers the coupling process. Nonetheless, useful catalysts and reaction conditions have been developed, specially by Fu's group, that allow the use of alkylhalides (and also alkyl organometallics) as coupling partners. ${ }^{29}$ No Pdcatalyzed alkyl coupling has been tried on polymeric substrates so far, and we decided to test our $\omega$-bromoalkyl-VAPNBs reported before. ${ }^{8}$ Polymer 16 was synthesized by copolymerization of norbornene and 2-( $\omega$-bromobutyl)-5-norbornene with $\left[\mathrm{Ni}\left(\mathrm{C}_{6} \mathrm{~F}_{5}\right)_{2}\left(\mathrm{SbPh}_{3}\right)_{2}\right]$ in an analogous reaction to that in Scheme 1 and following the procedure we described in the literature. $^{8}$

The Suzuki reaction was tested on polymer $16(2.7 \mathrm{mmol} \mathrm{Br}$ per $g ; a / b=1.5$ ) using the conditions described by Fu et al. for discrete alkylbromides (same as Method B in Table 2). Polymers 17-19 were obtained as greyish solids insoluble in most common organic solvents (Scheme 4). The substitution of bromide in the starting polymer $\mathbf{1 6}$ is almost complete in all cases (95-99\%). This is shown by the quantitative determination of the bromide content in polymers 17-19 as well as the disappearance of the band at $\nu\left(\mathrm{C}^{\mathrm{Alk}}-\mathrm{Br}\right)$ at $562 \mathrm{~cm}^{-1}$ present in 16.

Table 2 Functionalization of VA-PNB-NBC ${ }_{6} \mathrm{H}_{4} \mathrm{Br}$ by Suzuki reactions according to Scheme 3

\begin{tabular}{|c|c|c|c|c|c|}
\hline Entry & $\begin{array}{l}\text { VA-PNB, } a / b \\
\text { (mmol Br per g) }\end{array}$ & Method & Product VA-PNB & $\mathrm{Ar}$ & $\%$ Br subst. ${ }^{a}$ \\
\hline 1 & $3,1.6(2.5)$ & $\mathrm{A}^{b}$ & 5 & $\mathrm{C}_{6} \mathrm{H}_{5}$ & 94 \\
\hline 2 & $3,1.3(2.7)$ & $\mathrm{A}^{b}$ & 6 & $4-\mathrm{CF}_{3}-\mathrm{C}_{6} \mathrm{H}_{4}$ & 94 \\
\hline 3 & $3,4(1.6)$ & $\mathrm{A}^{b}$ & 6 & $4-\mathrm{CF}_{3}-\mathrm{C}_{6} \mathrm{H}_{4}$ & 93 \\
\hline 4 & $2,0(4)$ & $\mathrm{A}^{b}$ & 6 & $4-\mathrm{CF}_{3}-\mathrm{C}_{6} \mathrm{H}_{4}$ & 89 \\
\hline 5 & $3,1.3(2.7)$ & $A^{b}$ & 7 & $4-\mathrm{MeO}-\mathrm{C}_{6} \mathrm{H}_{4}^{-}$ & 62 \\
\hline 6 & $3,1.6(2.5)$ & $\mathrm{A}^{b}$ & 8 & 2-Me-4-MeO- $\mathrm{C}_{6} \mathrm{H}_{3}-$ & 62 \\
\hline 7 & $3,1(2.9)$ & $\mathrm{B}^{c}$ & 7 & $4-\mathrm{MeO}-\mathrm{C}_{6} \mathrm{H}_{4}^{-}$ & 95 \\
\hline 8 & $3,1.4(2.6)$ & $\mathrm{B}^{c}$ & 8 & $2-\mathrm{Me}-4-\mathrm{MeO}-\mathrm{C}_{6} \mathrm{H}_{3}-$ & 98 \\
\hline
\end{tabular}

${ }^{a}$ Determined by quantitative analyses of the bromine content in the polymer product. ${ }^{b}$ Method A: the reactions were carried out at $110{ }^{\circ} \mathrm{C}$ using toluene as solvent and $\left[\mathrm{PdCl}_{2} \mathrm{dppf}\right]$ as catalyst $(1 \mathrm{~mol} \%)$. Ratio of reagents: $\mathrm{ArB}(\mathrm{OH})_{2}: \mathrm{VAPNB}_{6} \mathrm{C}_{4}-\mathrm{Br}: \mathrm{K}_{2} \mathrm{CO}_{3}=2: 1: 2.5$. Reaction time $48 \mathrm{~h}$. ${ }^{c}$ Method B: the reactions were carried out at $100{ }^{\circ} \mathrm{C}$ using $t$-amylalcohol as solvent, $\left[\mathrm{Pd}_{2} \mathrm{dba}_{3}\right]$ as precatalyst $\left(2.5 \mathrm{~mol}^{\circ}\right)$, and $\mathrm{P}^{t} \mathrm{Bu}_{2} \mathrm{Me}(10$ mol\%). Ratio of reagents: $\operatorname{ArB}(\mathrm{OH})_{2}:$ VAPNB- $_{6} \mathrm{H}_{4}-\mathrm{Br}: \mathrm{KO}^{t} \mathrm{Bu}=1.5: 1: 3$. 
Table 3 Functionalization of $\mathrm{VA}-\mathrm{PNB}-\mathrm{NBC}_{6} \mathrm{H}_{4} \mathrm{Br}$ by Stille reactions according to Scheme $3^{a}$

\begin{tabular}{lllll}
\hline Entry & $\begin{array}{l}\text { VA-PNB, } a / b \\
(\mathrm{mmol} \text { Br per g) }\end{array}$ & $\begin{array}{l}\text { Product } \\
\text { VA-PNB }\end{array}$ & $\mathrm{R}^{1}$ & $\begin{array}{l}\% \mathrm{Br} \\
\text { subst. }\end{array}$ \\
\hline $1^{c}$ & $\mathbf{3}, 1.6(2.5)$ & $\mathbf{9}$ & $-\mathrm{CH}_{2} \mathrm{COCH}_{3}$ & 98 \\
$2^{d}$ & $\mathbf{3}, 1(2.9)$ & $\mathbf{1 0}$ & $-\mathrm{CH}=\mathrm{CH}_{2}$ & 75 \\
$3^{e}$ & $3,1.6(2.5)$ & $\mathbf{7}$ & $\mathrm{MeOC}_{6} \mathrm{H}_{4}-$ & 56
\end{tabular}

${ }^{a}$ The reactions were carried out at $110{ }^{\circ} \mathrm{C}$ for $48 \mathrm{~h}$ using toluene as solvent. ${ }^{b}$ Determined by quantitative analyses of the bromine content in the polymer product. ${ }^{c}\left[\mathrm{PdCl}_{2}\left\{\mathrm{P}\left(o-\mathrm{MeC}_{6} \mathrm{H}_{4}\right)_{3}\right\}_{2}\right]$ as catalyst $(1 \mathrm{~mol} \%)$. Ratio of reagents: $\mathrm{SnBu}_{3} \mathrm{R}^{1}$ : VAPNB-C ${ }_{6} \mathrm{H}_{4}-\mathrm{Br}=1.5: 1 .{ }^{d}\left[\mathrm{Pd}\left(\mathrm{PPh}_{3}\right)_{4}\right]$ as catalyst $(10 \mathrm{~mol} \%)$. Ratio of reagents: $\mathrm{SnBu}_{3} \mathrm{R}^{1}$ : VAPNB- $\mathrm{C}_{6} \mathrm{H}_{4}-\mathrm{Br}=$ $1.1: 1{ }^{e}\left[\mathrm{Pd}\left(\mathrm{PPh}_{3}\right)_{4}\right]$ as catalyst $(2 \mathrm{~mol} \%)$.

Since the elimination of bromide could occur easily in this case by $\beta-\mathrm{H}$ elimination after oxidative addition of the $\omega$ bromobutyl-VA-PNB, with little incorporation of the aryl moiety, we decided to check this possibility. Thus, we run the reaction in the same conditions used in the Suzuki couplings, but in the absence of the coupling partner, i.e. the boronic acid (Scheme 4). Polymer 20 was obtained which showed the presence of a terminal double bond both in the ${ }^{13} \mathrm{C}$ MAS-NMR spectrum (signals at 140 and $116 \mathrm{ppm}$ ) and in the IR spectrum (absorptions at $1640(\mathrm{~m})$ and $\left.908(\mathrm{~s}) \mathrm{cm}^{-1}\right)$. The bromide substitution was complete. Fig. 2 shows the IR spectra of polymers $\mathbf{1 7}$ and $\mathbf{2 0 .}$ As can be seen, the $\beta$-H elimination is not important in the Suzuki reactions and the most intense bands in the IR of $\mathbf{1 7}$ correspond to the phenyl group incorporated $\left(762,696 \mathrm{~cm}^{-1}\right)$. However, the presence of a terminal double bond cannot be completely excluded in $\mathbf{1 7}$ since there is a very low intensity band at $908 \mathrm{~cm}^{-1}$. The same applies to polymers 18 and 19.

\section{Elimination of the residual palladium in the functionalized polymers}

We analyzed the polymer products after the functionalization reactions in order to find out how much residual palladium was trapped in them. The ICP-MS quantitative data showed that the amount of $\mathrm{Pd}$ varies from $1.5 \mathrm{mg} \mathrm{g}^{-1}$ in the reactions where $1 \%$ mol of palladium catalysts is used to $5-10 \mathrm{mg} \mathrm{g}^{-1}$ if the amount of catalyst in the reaction is $5 \%$ mol. Several procedures to eliminate this residual metal were tested. Since the palladium occluded in the polymer is most probably black $\operatorname{Pd}(0)$ coming from the decomposition of the catalyst once the

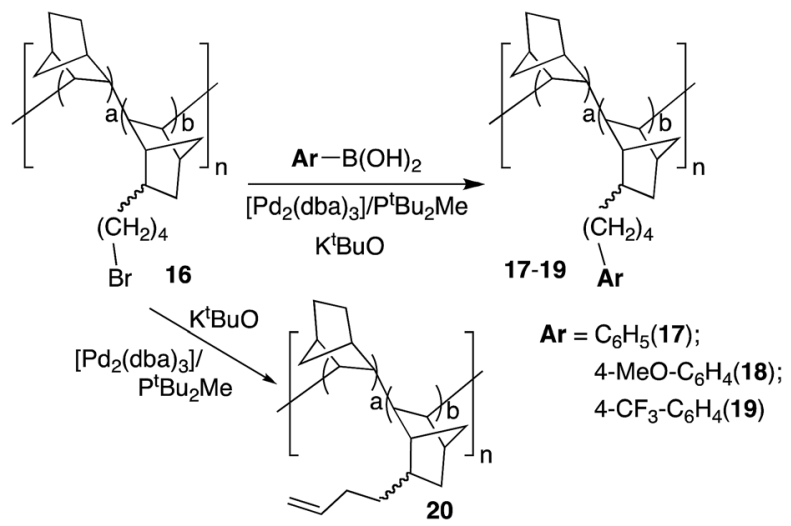

Scheme 4 Functionalization of VA-PNB 16 by Suzuki coupling and $\mathrm{Pd}$-catalyzed $\beta-\mathrm{H}$ elimination.

coupling reagents have been consumed, we decided to check if an oxidative addition reaction, to give a soluble $\mathrm{Pd}(\mathrm{II})$ complex, was a suitable cleaning way. A sample of polymer 6 containing $1.19 \mathrm{mg}$ Pd per $\mathrm{g}$ was mixed with an excess of 1-trifluoromethyl4 -iodobenzene and refluxed in toluene for $24 \mathrm{~h}$. The analysis of the polymer showed that only about $10 \%$ of the residual Pd was eliminated ( $1 \mathrm{mg}$ Pd per $\mathrm{g}$ remained). The reaction was carried out with a new sample of 6 (1.6 mg Pd per g) but adding $\mathrm{PPh}_{3}$ to increase the stability and solubility of the oxidative addition product (a putative $\left.\left[\mathrm{PdI}\left(4-\mathrm{CF}_{3}-\mathrm{C}_{6} \mathrm{H}_{4}\right)\left(\mathrm{PPh}_{3}\right)_{2}\right]\right)$. In this way half of the palladium in the polymer could be eliminated (from $1.6 \mathrm{mg}$ Pd per $\mathrm{g}$ in 6 to $0.8 \mathrm{mg}$ Pd per $\mathrm{g}$ after treatment).

Krebs et al. have used $N, N$-dimethyl-2-phenyldiazenecarbothioamide to remove palladium nanoparticles from polymers synthesized by Pd-catalyzed reactions. ${ }^{\mathbf{3 0}}$ They describe that this compound coordinates to $\operatorname{Pd}(0)$ and forms a soluble complex in most organic solvents. Thus, a sample of polymer 19 that contained $4.6 \mathrm{mg}$ Pd per $\mathrm{g}$ was treated with an excess of $\mathrm{N}, \mathrm{N}$-dimethyl-2-phenyldiazenecarbothioamide and refluxed in toluene for $24 \mathrm{~h}$. The cleaned 19 contained $0.47 \mathrm{mg}$ Pd per $g$, one order of magnitude lower than the initial amount, indicating that this is a superior method to that tested above. In general, this treatment leads to polymers that contain a palladium residue ten times lower than the initial amount (see ESI $\dagger$ ). The process can be repeated leading to a further reduction of $\mathrm{Pd}$, although about $400 \mathrm{ppm}$ is the lowest limit we have reached.

Table 4 Functionalization of VA-PNB-NBC ${ }_{6} \mathrm{H}_{4} \mathrm{Br}$ (3) by Buchwald-Hartwig aminations according to Scheme $3^{a}$

\begin{tabular}{|c|c|c|c|c|}
\hline Entry & VA-PNB, $a / b(\mathrm{mmol}$ Br per g) & Product VA-PNB & $\mathrm{NHR}^{2}$ & $\%$ Br subst. ${ }^{b}$ \\
\hline 1 & $3,1.4(2.6)$ & 12 & $\mathrm{NHC}_{6} \mathrm{H}_{5}$ & $>99$ \\
\hline 2 & $3,1.4(2.6)$ & 13 & $\mathrm{NH}-\mathrm{C}_{6} \mathrm{H}_{4}-4-\mathrm{MeO}$ & $>99$ \\
\hline 4 & $3,1.4(2.6)$ & 15 & $\mathrm{NH}-\mathrm{C}_{6} \mathrm{H}_{4}-4-\mathrm{NO}_{2}$ & $>99$ \\
\hline 5 & $3,1.4(2.6)$ & 16 & $\mathrm{NH}-\mathrm{C}_{6} \mathrm{H}_{3}-2,6-\mathrm{Me}_{2}$ & $>99$ \\
\hline
\end{tabular}

${ }^{a}$ The reactions were carried out at $110{ }^{\circ} \mathrm{C}$ for $48 \mathrm{~h}$ using toluene as solvent, $\left[\mathrm{Pd}_{2} \mathrm{dba}_{3}\right]$ as precatalyst $(1 \mathrm{~mol} \%)$ and X-Phos (6 mol\%). Ratio of reagents: $\mathrm{R}^{2}-\mathrm{NH}_{2}:$ VAPNB- $\mathrm{C}_{6} \mathrm{H}_{4}-\mathrm{Br}: \mathrm{KO}^{t} \mathrm{Bu}=2: 1: 2 .^{b}$ The polymer products do not contain any bromine as determined by quantitative analyses. 

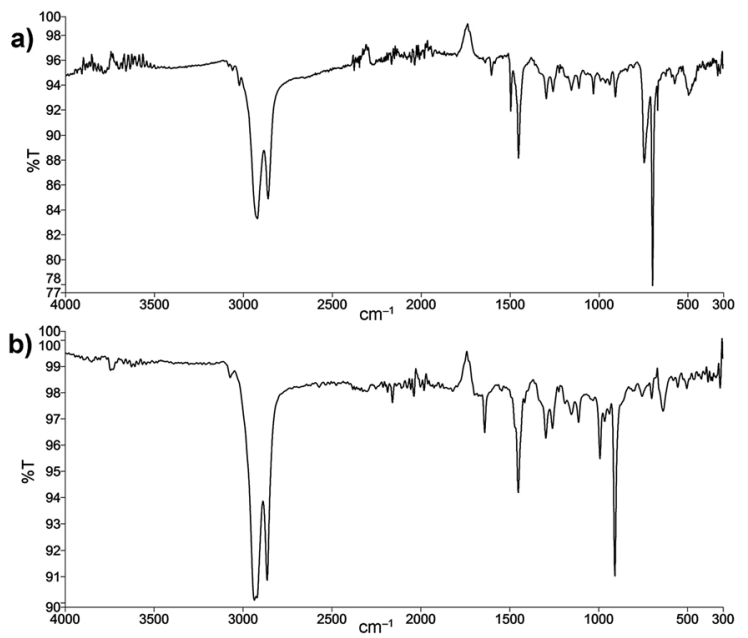

Fig. 2 IR spectra of polymers 17 (a) and 20 (b).

\section{Experimental}

\section{Materials and general considerations}

The compounds $\left[\mathrm{Ni}\left(\mathrm{C}_{6} \mathrm{~F}_{5}\right)_{2}\left(\mathrm{SbPh}_{3}\right)_{2}\right],{ }^{31} \quad\left[\mathrm{PdCl}_{2}(\mathrm{dppf})\right]^{32}$ $\left[\mathrm{Pd}\left(\mathrm{PPh}_{3}\right)_{4}\right],{ }^{33}$ and $\left[\mathrm{PdCl}_{2}\left(\mathrm{P}(o \text {-tolyl })_{3}\right)_{2}\right],{ }^{34}\left[\mathrm{Pd}_{2}(\mathrm{dba})_{3}\right],{ }^{35}\left[\mathrm{PdCl}_{2}(-\right.$ $\left.\left.\mathrm{PPh}_{3}\right)_{2}\right],{ }^{36} \mathrm{~N}, \mathrm{~N}$-dietilfenilazotioformamida, ${ }^{30}$ tributyl(4-methoxyphenyl)-stannane, ${ }^{37}$ and tributyl(vinyl)stannane, ${ }^{37}$ were prepared according to the literature procedures. Polymer VA$\operatorname{PNBNB}\left(\mathrm{CH}_{2}\right)_{4} \mathrm{Br}$ (16) was prepared as reported before. ${ }^{8}$ The other reagents used in this work were purchased from commercial suppliers and used without further purification. Solvents such as THF and $\mathrm{CH}_{2} \mathrm{Cl}_{2}$ were dried using a Solvent Purification System (SPS); toluene was dried over Na, distilled and deoxygenated prior to use. NMR spectra were recorded at $293 \mathrm{~K}$ using Bruker AV-400 and Agilent MR-500 instruments. Chemical shifts $(\delta)$ are reported in ppm and referenced to $\mathrm{SiMe}_{4}$ $\left({ }^{1} \mathrm{H},{ }^{13} \mathrm{C}\right)$ or $\mathrm{CFCl}_{3}\left({ }^{19} \mathrm{~F}\right)$. The solid state NMR spectra were recorded at room temperature under magic angle spinning (MAS) in a Bruker AV-400 spectrometer using a Bruker BL-4 probe with $4 \mathrm{~mm}$ diameter zirconia rotors spinning at $10 \mathrm{kHz}$. ${ }^{13} \mathrm{C}$ CP MAS NMR spectra were measured at $100.61 \mathrm{MHz}$ and recorded with proton decoupling (tppm), with $90^{\circ}$ pulse length of $4.5 \mu \mathrm{s}$ and a contact time of $3 \mathrm{~ms}$. Chemical shifts were calibrated indirectly through the glycine CO signal recorded at 176.0 ppm relative to TMS. ${ }^{31} \mathrm{P}$ MAS NMR spectra were recorded at $161.97 \mathrm{MHz}$ with proton decoupling (tppm), with a $90^{\circ}$ pulse length of $5.45 \mu \mathrm{s} .{ }^{31} \mathrm{P}-\mathrm{NMR}$ chemical shifts are in ppm relative to external $85 \% \mathrm{H}_{3} \mathrm{PO}_{4} \cdot{ }^{19} \mathrm{~F}$ MAS NMR spectra were recorded at $376.5 \mathrm{MHz}$ with a $90^{\circ}$ pulse length of $5.5 \mu \mathrm{s} .{ }^{19} \mathrm{~F}$ NMR chemical shifts are in ppm relative to external $\mathrm{CFCl}_{3}$. IR spectra were recorded either on neat samples using a Perkin-Elmer FT/IR SPECTRUM FRONTIER spectrophotometer with CsI + ATR diamond accessory in the range $200-4000 \mathrm{~cm}^{-1}$, or on $\mathrm{KBr}$ pellets using a Perkin-Elmer BX FT-IR in the range 400-4000 $\mathrm{cm}^{-1}$. Size exclusion chromatography (SEC) was carried out using a Waters SEC system on a three-column bed (Styragel 7.8 $\times 300$ mm columns: $50-10^{5}, 5 \times 10^{3}$ to $5 \times 10^{5}$ and $2 \times 10^{3}$ to 4 $\left.\times 10^{6} \mathrm{Da}\right)$ and a Waters 410 differential refractometer. SEC samples were run in $\mathrm{CHCl}_{3}$ at $313 \mathrm{~K}$ and calibrated to polystyrene standards. The bromine content in the polymers was determined by oxygen-flask combustion of a sample and analysis of the residue by mercurimetric titration of the bromide. ${ }^{38}$ The bromine content of the polymer $3(x=$ mmol Br per $\mathrm{g})$ and the polymer composition given as a ratio of monomers incorporated $(a / b=\mathrm{NB} / \mathbf{1})$ are related by the equation: $x=1000 /$ $(94.16(a / b)+249.155)$, where 94.16 and 249.155 are the molecular weights of norbornene and $\mathrm{NB}-\mathrm{C}_{6} \mathrm{H}_{4} \mathrm{Br}(\mathbf{1})$ respectively. The amount of residual palladium in the functionalized polymers was determined by ICP-MS, using Agilent 7500i equipment; the samples were dissolved in $\mathrm{HNO}_{3}(65 \%)$ using an ETHOS SEL Milestone microwave oven. Each analysis is the average of two independent determinations for each sample. $\mathrm{C}, \mathrm{H}$ and $\mathrm{N}$ elemental analyses were carried out using a Perkin-Elmer 2400 CHN microanalyzer.

Synthesis of 1. A mixture of 1-bromo-4-vinylbenzene $(2.0 \mathrm{~mL}$, $14.85 \mathrm{mmol})$, dicyclopentadiene $(1.0 \mathrm{~mL}, 7.43 \mathrm{mmol})$ and 2,6ditertbutylphenol $(0.46 \mathrm{~g}, 2.23 \mathrm{mmol})$ was heated at $180^{\circ} \mathrm{C}$ for 3 hours. The resulting mixture was precipitated by pouring the mixture into $n$-hexane $(30 \mathrm{~mL})$ and the solid was removed by filtration. The solvent was evaporated to dryness and the liquid obtained was distilled under reduced pressure $\left(150{ }^{\circ} \mathrm{C}, 0.6\right.$ $\mathrm{mmHg}$ ) and then it was chromatographed through a silica column using $n$-hexane as eluent. A colorless liquid was obtained, which was a $80: 20$ endo : exo mixture of isomers (1.24 $\mathrm{mL}, 44 \%$ yield). Elemental analysis: calcd (\%) for $\mathrm{C}_{13} \mathrm{H}_{13} \mathrm{Br}$ : C, 62.67; H, 5.26; found: C, 62.45; H, 5.20. MS (EI, $\mathrm{m} / \mathrm{z}(\%)): 250$, $248(10)\left[\mathrm{M}^{+}\right], 184,182(100)\left[\mathrm{M}^{+}\right.$- cyclopentene $], 103(26)\left[\mathrm{M}^{+}-\right.$ cyclopentene - Br], $77(24)\left[\mathrm{M}^{+}-\mathrm{NB}-\mathrm{Br}\right], 66(50)\left[\mathrm{M}^{+}-\right.$ $\left.\mathrm{CH}_{2} \mathrm{CHC}_{6} \mathrm{H}_{4} \mathrm{Br}\right]$.

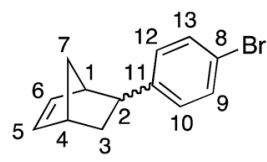

$1_{\text {exo. }}{ }^{1} \mathrm{H}$ NMR (400.13 MHz, $\left.\mathrm{CDCl}_{3}\right): \delta 7.42\left(\mathrm{~m}, 2 \mathrm{H}, \mathrm{H}^{9}, \mathrm{H}^{13}\right)$, $7.16\left(\mathrm{~m}, 2 \mathrm{H}, \mathrm{H}^{10}, \mathrm{H}^{12}\right), 6.26\left(\mathrm{dd}, J=5.71,2.78 \mathrm{~Hz}, 1 \mathrm{H}, \mathrm{H}^{6}\right), 6.18$ (dd, $J=5.71,2.94 \mathrm{~Hz}, 1 \mathrm{H}, \mathrm{H}^{5}$ ), $2.97\left(\mathrm{br}, 1 \mathrm{H}, \mathrm{H}^{4}\right), 2.86(\mathrm{br}, 1 \mathrm{H}$, $\left.\mathrm{H}^{1}\right), 2.68\left(\mathrm{~m}, 1 \mathrm{H}, \mathrm{H}^{2}\right), 1.75-1.6\left(\mathrm{~m}, 2 \mathrm{H}, \mathrm{H}^{3}\right), 1.5\left(\mathrm{~m}, 2 \mathrm{H}, \mathrm{H}^{7}\right) .{ }^{13} \mathrm{C}$ $\left\{{ }^{1} \mathrm{H}\right\}$ NMR (100.6 MHz, $\left.\mathrm{CDCl}_{3}\right): \delta 145.20\left(\mathrm{~s}, 1 \mathrm{C}, \mathrm{C}^{11}\right), 137.47(\mathrm{~s}$, $\left.1 \mathrm{C}, \mathrm{C}^{5}\right), 137.13\left(\mathrm{~s}, 1 \mathrm{C}, \mathrm{C}^{6}\right), 131.25\left(\mathrm{~s}, 2 \mathrm{C}, \mathrm{C}^{9}, \mathrm{C}^{13}\right), 129.35$ (s, 2C, $\left.\mathrm{C}^{10}, \mathrm{C}^{12}\right), 119.19\left(\mathrm{~s}, 1 \mathrm{C}, \mathrm{C}^{8}\right), 48.12\left(\mathrm{~s}, 1 \mathrm{C}, \mathrm{C}^{1}\right), 45.72\left(\mathrm{~s}, 1 \mathrm{C}, \mathrm{C}^{7}\right)$, 43.29 (s, 1C, $\left.\mathrm{C}^{2}\right), 42.33\left(\mathrm{~s}, 1 \mathrm{C}, \mathrm{C}^{4}\right), 33.77\left(\mathrm{~s}, 1 \mathrm{C}, \mathrm{C}^{3}\right)$.

$1_{\text {endo. }}{ }^{1} \mathrm{H}$ NMR $\left(400.13 \mathrm{MHz}, \mathrm{CDCl}_{3}\right): \delta 7.35\left(\mathrm{~m}, 2 \mathrm{H}, \mathrm{H}^{9}, \mathrm{H}^{13}\right)$, $7.02\left(\mathrm{~m}, 2 \mathrm{H}, \mathrm{H}^{10}, \mathrm{H}^{12}\right), 6.26\left(\mathrm{dd}, J=5.71,3.1 \mathrm{~Hz}, 1 \mathrm{H}, \mathrm{H}^{5}\right), 5.78$ (dd, $\left.J=5.71,2.78 \mathrm{~Hz}, 1 \mathrm{H}, \mathrm{H}^{6}\right), 3.35(\mathrm{~m}, J=9.29,4.78 \mathrm{~Hz}, 1 \mathrm{H}$, $\mathrm{H}^{2}$ ), 3.07 (br, $1 \mathrm{H}, \mathrm{H}^{1}$ ), 2.97 (br, $\left.1 \mathrm{H}, \mathrm{H}^{4}\right), 2.2$ (ddd, $J=11.9,9.29$, $\left.3.75 \mathrm{~Hz}, 1 \mathrm{H}, \mathrm{H}^{3}\right), 1.5\left(\mathrm{~m}, 2 \mathrm{H}, \mathrm{H}^{7}\right), 1.26$ (ddd, $J=11.3,4.89$, $\left.2.61 \mathrm{~Hz}, 1 \mathrm{H}, \mathrm{H}^{3^{\prime}}\right) .{ }^{13} \mathrm{C}\left\{{ }^{1} \mathrm{H}\right\} \mathrm{NMR}\left(100.6 \mathrm{MHz}, \mathrm{CDCl}_{3}\right): \delta 144.05(\mathrm{~s}$, $\left.1 \mathrm{C}, \mathrm{C}^{11}\right), 137.41\left(\mathrm{~s}, 1 \mathrm{C}, \mathrm{C}^{5}\right), 132.58\left(\mathrm{~s}, 1 \mathrm{C}, \mathrm{C}^{6}\right), 130.78\left(\mathrm{~s}, 2 \mathrm{C}, \mathrm{C}^{9}\right.$, $\left.\mathrm{C}^{13}\right), 129.84\left(\mathrm{~s}, 2 \mathrm{C}, \mathrm{C}^{10}, \mathrm{C}^{12}\right), 119.34\left(\mathrm{~s}, 1 \mathrm{C}, \mathrm{C}^{8}\right), 50.27\left(\mathrm{~s}, 1 \mathrm{C}, \mathrm{C}^{7}\right)$, $48.60\left(\mathrm{~s}, 1 \mathrm{C}, \mathrm{C}^{1}\right), 43.23\left(\mathrm{~s}, 1 \mathrm{C}, \mathrm{C}^{4}\right), 43.05\left(\mathrm{~s}, 1 \mathrm{C}, \mathrm{C}^{2}\right), 33.04$ $\left(\mathrm{s}, 1 \mathrm{C}, \mathrm{C}^{3}\right)$.

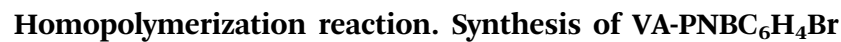
(2). $p$-Bromophenyl-norbornene (1) $(0.153 \mathrm{~mL}, 0.80 \mathrm{mmol})$ and 
dry $\mathrm{CH}_{2} \mathrm{Cl}_{2}(18.0 \mathrm{~mL})$ were mixed in a Schlenk flask under nitrogen. A solution of $\left[\mathrm{Ni}\left(\mathrm{C}_{6} \mathrm{~F}_{5}\right)_{2}\left(\mathrm{SbPh}_{3}\right)_{2}\right](0.0176 \mathrm{~g}, 0.016$ $\mathrm{mmol})$ in dry $\mathrm{CH}_{2} \mathrm{Cl}_{2}(2.0 \mathrm{~mL})$ was then added dropwise to the former solution. The starting orange solution got darker and the viscosity increased gradually. The mixture was stirred for $24 \mathrm{~h}$ at room temperature and then poured onto $\mathrm{MeOH}(50 \mathrm{~mL})$. A solid precipitated and it was stirred for $1 \mathrm{~h}$, filtered, washed with $\mathrm{MeOH}(3 \times 5 \mathrm{~mL})$ and air-dried. The homopolymer $(2)$ was obtained as an off-white solid. Isolated yield: $0.1005 \mathrm{~g}(50 \%) .{ }^{1} \mathrm{H}$ NMR (400.13 MHz, $\mathrm{CDCl}_{3}$ ): $\delta$ 7.6-7.4 (br, $\left.2 \mathrm{H}, \mathrm{H}^{9}, \mathrm{H}^{13}\right)$, 7.2-6.8 (br, $2 \mathrm{H}, \mathrm{H}^{10}, \mathrm{H}^{12}$ ), 3.4-3 (br, $\left.1 \mathrm{H}, \mathrm{H}^{2}\right), 2.8-0.5\left(\mathrm{br}, 8 \mathrm{H}, \mathrm{H}^{1}, \mathrm{H}^{3}-\mathrm{H}^{7}\right)$. ${ }^{13} \mathrm{C}\left\{{ }^{1} \mathrm{H}\right\}$ NMR (100.6 MHz, $\mathrm{CDCl}_{3}$ ): $\delta 141$ (br, $\left.1 \mathrm{C}, \mathrm{C}^{11}\right), 132-130$ (br, 2C, $\mathrm{C}^{9}, \mathrm{C}^{13}$ ), 130-128 (br, 2C, $\mathrm{C}^{10}, \mathrm{H}^{12}$ ), 119 (br, 1C, $\mathrm{C}^{8}$ ), 5030 (br, 7C, $\left.\mathrm{C}^{1}-\mathrm{C}^{7}\right) .{ }^{19} \mathrm{~F}$ NMR (376.5 $\mathrm{MHz}, \mathrm{CDCl}_{3}$ ): -135.7, -140, -142.8 (b, $\mathrm{F}_{\text {ortho }}, \mathrm{C}_{6} \mathrm{~F}_{5}$ ), -156.8 (b, $\left.\mathrm{F}_{\text {para }}, \mathrm{C}_{6} \mathrm{~F}_{5}\right),-162.2\left(\mathrm{~b}, \mathrm{~F}_{\text {meta }}\right.$, $\left.\mathrm{C}_{6} \mathrm{~F}_{5}\right)$. IR $\left(\mathrm{cm}^{-1}\right): \nu\left(\mathrm{C}^{\mathrm{Ar}}-\mathrm{Br}\right): 1075(\mathrm{~s}), \nu(\mathrm{CH} \delta$ oop $): 821$ (s). The polymer contains $319.2 \mathrm{mg}$ Br per $\mathrm{g}$ (3.99 mmol Br per $\mathrm{g}$ ).

Copolymerization reactions. Synthesis of VA-PNBNBC ${ }_{6} \mathrm{H}_{4} \mathrm{Br}$ (3) $\left(\boldsymbol{a} / \boldsymbol{b}=1.8\right.$, entry 3, Table 1). A solution of $\left[\mathrm{Ni}\left(\mathrm{C}_{6} \mathrm{~F}_{5}\right)_{2}\left(\mathrm{SbPh}_{3}\right)_{2}\right]$ $(0.0088 \mathrm{~g}, 0.008 \mathrm{mmol})$ in dry $\mathrm{CH}_{2} \mathrm{Cl}_{2}(2 \mathrm{~mL})$ was added dropwise to a mixture of $p$-bromophenylnorbornene $(0.0767 \mathrm{~mL}, 0.4$ $\mathrm{mmol})$, norbornene in $\mathrm{CH}_{2} \mathrm{Cl}_{2}(0.074 \mathrm{~mL}, 5.44 \mathrm{M}, 0.40 \mathrm{mmol})$ and dry $\mathrm{CH}_{2} \mathrm{Cl}_{2}(6.0 \mathrm{~mL}){ }^{39}$ The starting orange solution got darker and the viscosity increased gradually. The mixture was stirred for $10 \mathrm{~min}$ at room temperature and then it was poured onto $\mathrm{MeOH}$ $(50 \mathrm{~mL})$. A solid precipitated, which stirred for $1 \mathrm{~h}$, filtered, washed with $\mathrm{MeOH}(3 \times 5 \mathrm{~mL})$ and air-dried. The VA-PNB copolymer, 3, was obtained as off-white solid. Isolated yield: $0.0948 \mathrm{~g},(74 \%) .{ }^{1} \mathrm{H}$ NMR $\left(400.13 \mathrm{MHz}, \mathrm{CDCl}_{3}\right): \delta$ 7.6-7.4 (br, $2 \mathrm{H}$, $\left.\mathrm{H}^{9}, \mathrm{H}^{13}\right)$, 7.2-6.9 (br, 2H, $\left.\mathrm{H}^{10}, \mathrm{H}^{12}\right)$, 3.3-3 (br, 1H, $\left.\mathrm{H}^{2}\right), 2.8-0.5$ (br, $\left.8 \mathrm{H}, \mathrm{H}^{1}, \mathrm{H}^{3}-\mathrm{H}^{7}\right) .{ }^{13} \mathrm{C}\left\{{ }^{1} \mathrm{H}\right\} \mathrm{NMR}\left(100.6 \mathrm{MHz}, \mathrm{CDCl}_{3}\right): \delta 143-141(\mathrm{br}$, 1C, $\mathrm{C}^{11}$ ), 132-130.5 (br, 2C, $\mathrm{C}^{9}, \mathrm{C}^{13}$ ), 130.5-128.5 (br, 2C, $\mathrm{C}^{10}, \mathrm{C}^{12}$ ), 119 (br, 1C, $\mathrm{C}^{8}$ ), 50.5 (br, 1C, $\mathrm{C}^{7}$ ), 45.5 (br, 2C, $\mathrm{C}^{1}, \mathrm{C}^{4}$ ), 39 (br, 1C, $\mathrm{C}^{5}$ ), 35 (br, 1C, $\mathrm{C}^{6}$ ), 30.5 (br, 1C, $\mathrm{C}^{2}$ ), 30 (br, 1C, $\mathrm{C}^{3}$ ). ${ }^{19} \mathrm{~F}$ NMR $\left(376.5 \mathrm{MHz}, \mathrm{CDCl}_{3}\right)$ : -140.5 (b, $\left.\mathrm{F}_{\text {ortho }}, \mathrm{C}_{6} \mathrm{~F}_{5}\right),-157.8$ (b, $\mathrm{F}_{\text {para }}$, $\left.\mathrm{C}_{6} \mathrm{~F}_{5}\right),-162.7$ (b, $\left.\mathrm{F}_{\text {meta }}, \mathrm{C}_{6} \mathrm{~F}_{5}\right)$. IR $\left(\mathrm{cm}^{-1}\right): \nu\left(\mathrm{C}^{\mathrm{Ar}}-\mathrm{Br}\right): 1075(\mathrm{~s})$, $\nu$ (CHooop): 821 (s). The polymer contains $2.4 \mathrm{mmol} \mathrm{Br}$ per $\mathrm{g}$, which corresponds to a NB: $\mathrm{NBC}_{6} \mathrm{H}_{4} \mathrm{Br}=a: b=1.8: 1$ ratio. The other copolymerization reactions were carried out in a similar way using a different monomer feed ratio as collected in Table 1.

\section{Functionalization of VA-PNBNBC ${ }_{6} \mathrm{H}_{4} \mathrm{Br}$}

Synthesis of [VA-PNBNBC ${ }_{6} \mathrm{H}_{4}-\operatorname{PdBr}\left(\mathrm{PPh}_{3}\right)_{2}$ ] (4). Polymer 3 $(0.259 \mathrm{~g}, 0.7416 \mathrm{mmol}$ of $\mathrm{Br}),\left[\mathrm{Pd}\left(\mathrm{PPh}_{3}\right)_{4}\right](0.857 \mathrm{~g}, 0.7416 \mathrm{mmol})$ and dry toluene $(15 \mathrm{~mL})$ were added in a Schlenk flask under $\mathrm{N}_{2}$. The reaction mixture was heated at $80{ }^{\circ} \mathrm{C}$ for $8 \mathrm{~h}$. After that time, the solid was filtered, washed several times with $\mathrm{Et}_{2} \mathrm{O}(6 \times 3 \mathrm{~mL})$ and vacuum dried. The product was obtained as a light brown solid. Isolated yield: $0.314 \mathrm{~g}(43 \%) .{ }^{13} \mathrm{C}$ CP-MAS NMR (100.61 $\mathrm{MHz}$ ): $\delta$ 153-144 (br, 8C, C ${ }^{8}, \mathrm{C}^{11}, \mathrm{C}_{i p s o}-\mathrm{PPh}_{3}$ ), 141-117 (br, 34C, $\mathrm{C}^{9}, \mathrm{C}^{10}, \mathrm{C}^{12}, \mathrm{C}^{13}, \mathrm{C}_{\text {ortho }}-\mathrm{PPh}_{3}, \mathrm{C}_{\text {meta }}-\mathrm{PPh}_{3}, \mathrm{C}_{\text {para }}-\mathrm{PPh}_{3}$ ), 61-20 (br, 7C, $\left.\mathrm{C}^{1}-\mathrm{C}^{7}\right) .{ }^{31} \mathrm{P}$ MAS NMR (161.97 MHz): $\delta 26\left(\mathrm{br}, \mathrm{PPh}_{3}\right)$. IR $\left(\mathrm{cm}^{-1}\right): \nu\left(\mathrm{C}^{\mathrm{Ar}}-\mathrm{H} \delta\right.$ oop$): 743(\mathrm{~m}), 693(\mathrm{~s}), \nu(\mathrm{Pd}-\mathrm{P}): 539(\mathrm{~m}), 513$ (vs.), $\nu(\mathrm{Pd}-\mathrm{Br}): 303(\mathrm{w})$.

Suzuki reactions. Method A. Synthesis of VA-PNBNBC ${ }_{6} \mathrm{H}_{4}-\mathrm{Ph}$ (5). Entry 1, Table 2. Polymer 3 (0.1 g, $0.2549 \mathrm{mmol}$ of $\mathrm{Br}$ ), phenylboronic acid (0.062 g, $0.5098 \mathrm{mmol}), \mathrm{K}_{2} \mathrm{CO}_{3}(0.088 \mathrm{~g}$, $0.6373 \mathrm{mmol})$, and $\left[\mathrm{PdCl}_{2}(\mathrm{dppf})\right](0.0018 \mathrm{~g}, 0.0025 \mathrm{mmol})$ and dry toluene $(5 \mathrm{~mL})$ were added to a Schlenk flask under $\mathrm{N}_{2}$. The reaction mixture was heated at $110{ }^{\circ} \mathrm{C}$ for $48 \mathrm{~h}$. After that time, the solution was poured onto $\mathrm{MeOH}(50 \mathrm{~mL})$. A solid precipitated, which was stirred for $30 \mathrm{~min}$. The solid was filtered, washed several times with a mixture of diluted $\mathrm{HCl}(\mathrm{aq}) / \mathrm{MeOH}$ and then $\mathrm{MeOH}(3 \times 5 \mathrm{~mL})$ and air-dried. The copolymer was obtained as a brownish solid. Isolated yield: $0.0842 \mathrm{~g}(85 \%)$. The polymer contains $0.14 \mathrm{mmol} \mathrm{Br}$ per $\mathrm{g}$, which indicates $94 \%$ of $\mathrm{Br}$ substitution. ${ }^{13} \mathrm{C}$ CP-MAS NMR (100.61 MHz): $\delta$ 150-137 (br, 3C, $\left.\mathrm{C}^{8}, \quad \mathrm{C}^{11}, \quad \mathrm{C}_{i p s o}^{\mathrm{Ph}}\right), \quad 135-123\left(\mathrm{br}, 9 \mathrm{C}, \mathrm{C}^{9}, \mathrm{C}^{10}, \mathrm{C}^{12}, \mathrm{C}^{13}\right.$, $\left.\mathrm{C}_{\text {ortho }}^{\mathrm{Ph}}, \mathrm{C}_{\text {meta }}^{\mathrm{Ph}}, \mathrm{C}_{\text {para }}^{\mathrm{Ph}}\right), 64-17$ (br, 7C, $\left.\mathrm{C}^{1}-\mathrm{C}^{7}\right)$. IR ( $\left.\mathrm{cm}^{-1}\right): \nu(\mathrm{CH} \delta$ oop):

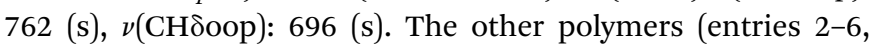
Table 2) were prepared in the same way but using the corresponding arylboronic acid.

VA-PNBNBC ${ }_{6} \mathrm{H}_{4}-\mathrm{C}_{6} \mathrm{H}_{4}-\mathbf{4}-\mathrm{CF}_{3}$ (6). Entry 2, Table 2. ${ }^{13} \mathrm{C} \mathrm{CP}-$ MAS NMR (100.61 MHz): $\delta$ 153-144 (br, 3C, $\mathrm{C}^{8}, \mathrm{C}^{11}$, $\mathrm{C}_{\text {ipso }}^{\mathrm{Ar}}$ ), 142-136 (br, 1C, $\mathrm{C}_{\text {para }}^{\mathrm{Ar}} C_{\mathrm{CF}}$ ), 135-117 (br, 9C, $\mathrm{C}^{9}, \mathrm{C}^{10}, \mathrm{C}^{12}$, $\left.\mathrm{C}^{13}, \mathrm{C}_{\text {ortho }}^{\mathrm{Ar}}, \mathrm{C}_{\text {meta }}^{\mathrm{Ar}}, \mathrm{CF}_{3}\right), 61-22$ (br, 7C, $\left.\mathrm{C}^{1}-\mathrm{C}^{7}\right) .{ }^{19} \mathrm{~F}$ MAS (376.49 MHz): $\delta-61$ (br). IR ( $\left.\mathrm{cm}^{-1}\right): \nu(\mathrm{C}-\mathrm{Fst}): 1327$ (vs.), 1167 (vs.), 1125 (vs.), $\nu$ (CHסoop): 823 (vs.). The copolymer contains $0.15 \mathrm{mmol}$ $\mathrm{Br}$ per $\mathrm{g}$, which indicates $94 \%$ of $\mathrm{Br}$ substitution.

VA-PNBNBC ${ }_{6} \mathbf{H}_{4}-\mathrm{C}_{6} \mathrm{H}_{3}-2$-Me-4-OMe (8). Entry 6, Table $2 .{ }^{13} \mathrm{C}$ CP-MAS NMR (100.61 MHz): $\delta$ 161-159 (br, 1C, $\mathrm{C}_{\text {para }}^{\mathrm{Ar}}$ COMe), 149-125 (br, 9C, $\mathrm{C}^{8}-\mathrm{C}^{13}, \mathrm{C}_{\text {ortho }}^{\mathrm{Ar}}, \mathrm{C}_{\text {ipso }}^{\mathrm{Ar}}$ ), 123-118 (s, 2C, $\mathrm{C}_{\text {meta }}^{\mathrm{Ar}}$ ), 6520 (br, 9C, $\mathrm{C}^{1}-\mathrm{C}^{7}, \mathrm{CH}_{3} \mathrm{O}, \mathrm{CH}_{3}$ ). IR ( $\left.\mathrm{cm}^{-1}\right): \nu$ (COCst as): 1235 (vs.), $\nu$ (COCst sim): $1055(\mathrm{~m})$. The copolymer contains $0.87 \mathrm{mmol} \mathrm{Br}$ per $\mathrm{g}$, which indicates $62 \%$ of $\mathrm{Br}$ substitution.

Method B. Synthesis of VA-PNBNBC $6 \mathrm{H}_{4}-\mathrm{C}_{6} \mathrm{H}_{4}-4-\mathrm{OMe}$ (7). Entry 7, Table 2. A mixture of polymer $3(0.2 \mathrm{~g}, 0.573 \mathrm{mmol}$ of $\mathrm{Br})$, 2-methyl-2-butanol (10 mL), 4-methoxyphenylboronic acid (0.1306 g, $0.86 \mathrm{mmol}), \mathrm{K}^{t} \mathrm{BuO}(0.2101 \mathrm{~g}, 1.719 \mathrm{mmol}), \mathrm{P}\left({ }^{t} \mathrm{Bu}\right)_{2} \mathrm{Me}$ $(0.011 \mathrm{~mL}, 0.057 \mathrm{mmol}),\left[\mathrm{Pd}_{2}(\mathrm{dba})_{3}\right](0.0148 \mathrm{~g}, 0.0143 \mathrm{mmol})$ was heated at $100{ }^{\circ} \mathrm{C}$ in a $\mathrm{N}_{2}$ atmosphere for $48 \mathrm{~h}$. Then, the resulting mixture was poured into $\mathrm{MeOH}(50 \mathrm{~mL})$ and stirred for 30 minutes. The resulting solid was collected by vacuum filtration, washed with $\mathrm{MeOH}(3 \times 10 \mathrm{~mL})$ and air-dried. The copolymer was obtained as a greyish solid. Isolated yield: $0.2007 \mathrm{~g}$ (94\%). The copolymer contains $0.14 \mathrm{mmol} \mathrm{Br}$ per $\mathrm{g}$, which indicates $95 \%$ of $\mathrm{Br}$ substitution. ${ }^{13} \mathrm{C}$ CP-MAS NMR (100.61 MHz): $\delta 160$ (s, 1C, $\mathrm{C}_{\text {para }}^{\mathrm{Ar}}$ ), 150-137 (br, 1C, $\mathrm{C}^{11}$ ), 136-122 (br, 8C, $\mathrm{C}^{8}-\mathrm{C}^{10}, \mathrm{C}^{12}, \mathrm{C}^{13}, \mathrm{C}_{\text {ipso }}^{\mathrm{Ar}}, \mathrm{C}_{\text {ortho }}^{\mathrm{Ar}}$ ), 115 (s, 2C, $\mathrm{C}_{\text {meta }}^{\mathrm{Ar}}$ ), 65-20 (br, 8C, $\mathrm{C}^{1-7}, \mathrm{CH}_{3} \mathrm{O}$ ). IR ( $\mathrm{cm}^{-1}$ ); $\nu$ (COCst as): 1246 (vs.), $\nu$ (COCst sim): $1044(\mathrm{~m})$.

Stille reactions. Synthesis of VA-PNBNBC ${ }_{6} \mathrm{H}_{4}-\mathrm{CH}_{2} \mathrm{C}(\mathrm{O}) \mathrm{CH}_{3}$ (9). A mixture of polymer $3(0.2 \mathrm{~g}, 0.5098 \mathrm{mmol}$ of $\mathrm{Br})$, dry toluene $(7 \mathrm{~mL}), \quad \mathrm{SnBu}_{3}(\mathrm{OMe})(0.22 \mathrm{~mL}, 0.7504 \mathrm{mmol})$, $\mathrm{AcOCMe}=\mathrm{CH}_{2}(0.082 \mathrm{~mL}, 0.7504 \mathrm{mmol})$ and $\left[\mathrm{PdCl}_{2}(\mathrm{P}(o-\right.$ tolyl $\left.\left.)_{3}\right)_{2}\right](0.004 \mathrm{~g}, 0.005 \mathrm{mmol})$ in a $\mathrm{N}_{2}$ atmosphere, was heated at $110{ }^{\circ} \mathrm{C}$ for $48 \mathrm{~h}$. After that time, the solution was poured onto $\mathrm{MeOH}(30 \mathrm{~mL})$, then was filtered, washed several times with $\mathrm{MeOH}(3 \times 5 \mathrm{~mL})$ and dried under vacuum. The product was obtained as a greyish solid. Isolated yield: $0.1773 \mathrm{~g}$ (77\%). The copolymer contains $0.07 \mathrm{mmol}$ Br per $\mathrm{g}$, which indicates $98 \%$ of Br substitution. ${ }^{13} \mathrm{C}$ CP-MAS NMR (100.61 MHz): $\delta 205$ (s, 1C, 
CO), 151-139 (br, 1C, $\mathrm{C}^{11}$ ), 138-121 (br, 5C, $\mathrm{C}^{8}-\mathrm{C}^{10}, \mathrm{C}^{12}, \mathrm{C}^{13}$ ), 67-17 (br, 9C, $\left.\mathrm{C}^{1}-\mathrm{C}^{7}, \mathrm{CH}_{2} \mathrm{C}(\mathrm{O}) \mathrm{CH}_{3}\right)$. IR ( $\left.\mathrm{cm}^{-1}\right)$; $\nu(\mathrm{CO}): 1720$ (s).

Synthesis of VA-PNBNBC $\mathbf{H}_{4}-\mathbf{C H}=\mathbf{C H}_{2}$ (10). A mixture of polymer $3(0.1 \mathrm{~g}, 0.2865 \mathrm{mmol}$ of $\mathrm{Br}), \mathrm{SnBu}_{3} \mathrm{CH}=\mathrm{CH}_{2}(0.095$ $\mathrm{mL}, 0.3152 \mathrm{mmol}),\left[\mathrm{Pd}\left(\mathrm{PPh}_{3}\right)_{4}\right](0.0331 \mathrm{~g}, 0.0286 \mathrm{mmol})$ and dry toluene $(10 \mathrm{~mL})$ was heated in a Schlenk flask under a $\mathrm{N}_{2}$ atmosphere at $110{ }^{\circ} \mathrm{C}$ for $48 \mathrm{~h}$. After that time, the mixture was poured onto $\mathrm{MeOH}(30 \mathrm{~mL})$. The solid was filtered, washed several times with $\mathrm{MeOH}(3 \times 5 \mathrm{~mL})$ and air-dried. The product was obtained as a greyish solid. Isolated yield: $0.0917 \mathrm{~g}$ (99\%). The copolymer contains $0.76 \mathrm{mmol} \mathrm{Br}$ per $\mathrm{g}$, which indicates $75 \%$ of Br substitution. ${ }^{13} \mathrm{C}$ CP-MAS NMR (100.61 MHz): $\delta 154-$ 140 (br, 2C, $\mathrm{C}^{8}, \mathrm{C}^{11}$ ), 140-135 (br, 2C, $\mathrm{CH}=\mathrm{CH}_{2}$ ), 135-127 (br, $\left.4 \mathrm{C}, \mathrm{C}^{9}, \mathrm{C}^{10}, \mathrm{C}^{12}, \mathrm{C}^{13}\right), 67-22\left(\mathrm{br}, 7 \mathrm{C}, \mathrm{C}^{1}-\mathrm{C}^{7}\right) . \mathrm{IR}\left(\mathrm{cm}^{-1}\right) ; \nu(\mathrm{C}=\mathrm{Cst})$ :

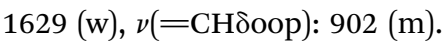

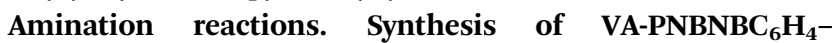
$\mathbf{N H}\left(\mathbf{C}_{6} \mathbf{H}_{4}-3-\mathbf{C F}_{3}\right)$ (13). Polymer $3(0.2 \mathrm{~g}, 0.54 \mathrm{mmol}), \mathrm{KO}^{t} \mathrm{Bu}$ (0.132 g, $1.08 \mathrm{mmol}), 3$-(trifluoromethyl)aniline (0.134 mL, 1.08 $\mathrm{mmol})$, X-Phos (0.0154 g, $0.0324 \mathrm{mmol})$, and $\mathrm{Pd}_{2}(\mathrm{dba})_{3}$ $(0.0056 \mathrm{~g}, 0.0054 \mathrm{mmol})$ were added to dry and deoxygenated toluene $(10 \mathrm{~mL})$ in a Schlenk flask under a $\mathrm{N}_{2}$ atmosphere. The reaction mixture was heated at $110{ }^{\circ} \mathrm{C}$ for 48 hours. The mixture was then poured onto $\mathrm{MeOH}(50 \mathrm{~mL})$. A solid precipitated and it was stirred for 30 minutes, filtered, washed with $\mathrm{MeOH}(3 \times 5$ $\mathrm{mL}$ ), and air-dried. The polymer was obtained as a greyish solid. Isolated yield: $0.223 \mathrm{~g}$ (91\%). The polymer contains $0 \mathrm{mmol} \mathrm{Br}$ per $\mathrm{g}$ which indicates complete $\mathrm{Br}$ substitution. ${ }^{13} \mathrm{C}$ CP-MAS NMR (100.61 MHz): $\delta$ 154-137 (br, 3C, $\mathrm{C}^{8}, \mathrm{C}^{11}, \mathrm{C}_{i p s o}^{\mathrm{Ar}}$ ), 135-108 (br, 10C, $\left.\mathrm{C}^{9}, \mathrm{C}^{10}, \mathrm{C}^{12}, \mathrm{C}^{13}, \mathrm{C}_{\text {para }}^{\mathrm{Ar}}, \mathrm{C}_{\text {ortho }}^{\mathrm{Ar}}, \mathrm{C}_{\text {meta }}^{\mathrm{Ar}}, C \mathrm{~F}_{3}\right), 65-21(\mathrm{br}, 7 \mathrm{C}$, $\left.\mathrm{C}^{1}-\mathrm{C}^{7}\right) .{ }^{19} \mathrm{~F}$ MAS (376.49 MHz): $\delta-61$ (br). IR $\left(\mathrm{cm}^{-1}\right) ; \nu(\mathrm{CF}): 697$, $\nu$ (CFst): 1334, 1163, 1124, $\nu$ (NHst): 3403 (w), $\nu$ (CNst): 1279 (m). The other polymers in Table 4 were prepared in the same way but using the corresponding aniline. All of them contain $0 \mathrm{mmol} \mathrm{Br}$ per $\mathrm{g}$ which indicates complete of $\mathrm{Br}$ substitution.

VA-PNBNBC $6 \mathbf{H}_{4}-\mathbf{N H P h}$ (11). ${ }^{13} \mathrm{C}$ CP-MAS NMR (100.61 MHz): $\delta$ 150-139 (br, 3C, $\left.\mathrm{C}^{8}, \mathrm{C}^{11}, \mathrm{C}_{i p s o}^{\mathrm{Ph}}\right), 135-126$ (br, 4C, $\mathrm{C}^{10}, \mathrm{C}^{12}$, $\mathrm{C}_{\text {para }}^{\mathrm{Ph}}$ ), 125-112 (br, 6C, $\mathrm{C}^{9}, \mathrm{C}^{13}, \mathrm{C}_{\text {ortho }}^{\mathrm{Ph}}, \mathrm{C}_{\text {meta }}^{\mathrm{Ph}}$ ), 65-21 (br, 7C, $\mathrm{C}^{1}-$ $\left.\mathrm{C}^{7}\right)$. IR ( $\left.\mathrm{cm}^{-1}\right) ; \nu$ (NHst): 3399 (w), $\nu$ (CNst): 1307 (m).

VA-PNBNBC $6 \mathrm{H}_{4}-\mathrm{NH}\left(\mathrm{C}_{6} \mathrm{H}_{4}-4-\mathrm{OMe}\right)$ (12). ${ }^{13} \mathrm{C}$ CP-MAS NMR (100.61 MHz): $\delta 161-153\left(\mathrm{br}, 1 \mathrm{C}, \mathrm{C}_{\text {para }}^{\mathrm{Ar}}\right.$ ), 150-125 (br, 9C, $\mathrm{C}^{8}-\mathrm{C}^{13}$, $\mathrm{C}_{\text {ipso }}^{\mathrm{Ph}}, \mathrm{C}_{\text {ortho }}^{\mathrm{Ph}}$ ), 120-110 (br, 2C, $\mathrm{C}_{\text {meta }}^{\mathrm{Ar}}$ ), 63-23 (br, 8C, $\mathrm{C}^{1}-\mathrm{C}^{7}$, $\left.\mathrm{CH}_{3} \mathrm{O}\right)$. IR $\left(\mathrm{cm}^{-1}\right)$; $\nu(\mathrm{C}-\mathrm{O}-\mathrm{Cst}$ as $): 1236, \nu(\mathrm{C}-\mathrm{O}-\mathrm{Cst}$ sim): 1037, $\nu$ (NHst): 3395 (w), $\nu$ (CNst): $1296(\mathrm{~m})$.

VA-PNBNBC ${ }_{6} \mathrm{H}_{4}-\mathrm{NH}\left(\mathrm{C}_{6} \mathrm{H}_{4}-4-\mathrm{NO}_{2}\right)$ (14). ${ }^{13} \mathrm{C}$ CP-MAS NMR (100.61 MHz): $\delta$ 153-147 (br, 1C, $\mathrm{C}_{i p s o}^{\mathrm{Ar}}$ ), 145-135 (br, 3C, $\mathrm{C}^{8}, \mathrm{C}^{11}$, $\left.\mathrm{C}_{\text {para }}^{\mathrm{Ar}}\right), 134-110$ (br, 8C, $\left.\mathrm{C}^{9}, \mathrm{C}^{10}, \mathrm{C}^{12}, \mathrm{C}^{13}, \mathrm{C}_{\text {ortho }} \mathrm{Ar}, \mathrm{C}_{\text {meta }}^{\mathrm{Ar}}\right), 64-24$ (br, 7C, $\left.\mathrm{C}^{1}-\mathrm{C}^{7}\right)$. IR $\left(\mathrm{cm}^{-1}\right)$; $\nu\left(\mathrm{NO}_{2}\right.$ stas $): 1503, \nu\left(\mathrm{NO}_{2}\right.$ stsim): 1302,

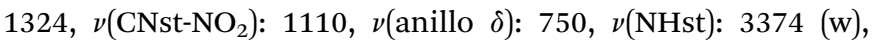
$\nu$ (CNst): $1252(\mathrm{~m})$.

VA-PNBNBC $6 \mathrm{H}_{4}-\mathrm{NH}\left(\mathrm{C}_{6} \mathrm{H}_{3}-2,6\right.$-diMe $)(15) .{ }^{13} \mathrm{C}$ CP-MAS NMR (100.61 MHz): $\delta$ 149-143 (br, 1C, $\mathrm{C}_{\text {para }}^{\mathrm{Ar}}$ ), 143-122 (br, 9C, $\mathrm{C}^{8}-\mathrm{C}^{13}$, $\mathrm{C}_{\text {ipso }}^{\mathrm{Ar}}, \mathrm{C}_{\text {ortho }}^{\mathrm{Ar}}$ ), 120-110 (br, 2C, $\left.\mathrm{C}_{\text {meta }}^{\mathrm{Ar}}\right), 66-25$ (br, 7C, $\left.\mathrm{C}^{1}-\mathrm{C}^{7}\right), 24-15$ (br, 2C, $\mathrm{CH}_{3}$ ). IR (cm ${ }^{-1}$ ); $\nu$ (NHst): 3408 (w), $\nu$ (CNst): 1295 (m).

Functionalization of VA-PNBNB $\left(\mathrm{CH}_{2}\right)_{4} \mathrm{Br}$. Synthesis of VA$\operatorname{PNBNB}\left(\mathbf{C H}_{2}\right)_{\mathbf{4}} \mathbf{P h}$ (17). A mixture of polymer 17 (0.2 g, 0.5342 mmol), phenylboronic acid (0.0977 g, $0.8013 \mathrm{mmol}), \mathrm{K}^{t} \mathrm{BuO}$ (0.1958 g, $1.6026 \mathrm{mmol}), \mathrm{P}\left({ }^{t} \mathrm{Bu}\right)_{2} \mathrm{Me}(0.0104 \mathrm{~mL}, 0.0534 \mathrm{mmol})$,
$\mathrm{Pd}_{2}(\mathrm{dba})_{3}(0.0138 \mathrm{~g}, 0.0134 \mathrm{mmol})$ and 2-methyl-2-butanol (5 $\mathrm{mL}$ ) was heated at $100{ }^{\circ} \mathrm{C}$ with stirring, under $\mathrm{N}_{2}$, for $48 \mathrm{~h}$. Then, the resulting mixture was poured onto $\mathrm{MeOH}(30 \mathrm{~mL})$ and stirred for 30 minutes. The resulting solid was collected by vacuum filtration, washed with $\mathrm{MeOH}(3 \times 5 \mathrm{~mL})$, and air-dried. The copolymer was obtained as a greyish solid. Isolated yield: $0.1871 \mathrm{~g}$ (94\%). The copolymer contains $0.08 \mathrm{mmol} \mathrm{Br}$ per $\mathrm{g}$, which indicates $97 \%$ of $\mathrm{Br}$ substitution. ${ }^{13} \mathrm{C}$ CP-MAS NMR (100.61 MHz): $\delta$ 147-137 (br, 1C, $\mathrm{C}_{i p s o}^{\mathrm{Ph}}$ ), 136-128 (br, 5C, $\left.\mathrm{C}_{\text {ortho }}^{\mathrm{Ph}}, \mathrm{C}_{\text {meta }}^{\mathrm{Ph}}, \mathrm{C}_{\text {para }}^{\mathrm{Ph}}\right), 67-23$ (br, $\left.11 \mathrm{C}, \mathrm{C}^{1}-\mathrm{C}^{7}, \mathrm{CH}_{2} \mathrm{Bu}, \mathrm{CH}_{3} \mathrm{Bu}\right) . \mathrm{IR}$

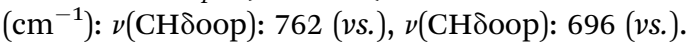

Polymers 19 and 20 were prepared in the same way but using the corresponding boronic acid.

VA-PNBNB $\left(\mathrm{CH}_{2}\right)_{4}-\mathrm{C}_{6} \mathrm{H}_{4}-\mathbf{4 - O M e} \quad(\mathbf{1 8}) .{ }^{13} \mathrm{C}$ CP-MAS NMR (100.61 MHz): $\delta 160$ (s, 1C, $\left.\mathrm{C}_{i p s o}^{\mathrm{Ar}} \mathrm{OMe}\right), 143-127$ (br, 4C, $\mathrm{C}_{m e t a}^{\mathrm{Ar}}$, $\mathrm{C}_{\text {para }}^{\mathrm{Ar}}$ ), 115 (s, 1C, $\mathrm{C}_{\text {ortho }}^{\mathrm{Ar}}$ ) 64-22 (br, 12C, $\mathrm{C}^{1}-\mathrm{C}^{7}, \mathrm{CH}_{3} \mathrm{O}, \mathrm{CH}_{2} \mathrm{Bu}$, $\left.\mathrm{CH}_{3} \mathrm{Bu}\right)$. IR ( $\left.\mathrm{cm}^{-1}\right): \nu$ (COCstas): 1235 (vs.), $\nu$ (COCstsim): 1055 (m). The copolymer contains $0 \mathrm{mmol} \mathrm{Br}$ per $\mathrm{g}$, which indicates complete Br substitution.

VA-PNBNB $\left(\mathrm{CH}_{2}\right)_{\mathbf{4}}-\mathrm{C}_{6} \mathbf{H}_{4}-\mathbf{4}-\mathrm{CF}_{3} \quad$ (19). ${ }^{13} \mathrm{C} \quad \mathrm{CP}-\mathrm{MAS} \quad \mathrm{NMR}$ (100.61 MHz): $\delta 149$ (s, 1C, $\left.\mathrm{C}_{\text {para }}^{\mathrm{Ar}}\right), 142\left(\mathrm{~s}, 1 \mathrm{C}, \mathrm{C}_{\text {ipso }}^{\mathrm{Ph}} \mathrm{CF}_{3}\right), 136-120$ (br, 5C, $\left.\mathrm{C}_{\text {ortho }}^{\mathrm{Ph}}, \mathrm{C}_{\text {meta }}^{\mathrm{Ph}}, \mathrm{CF}_{3}\right), 65-20\left(\mathrm{br}, 11 \mathrm{C}, \mathrm{C}^{1}-\mathrm{C}^{7}, \mathrm{CH}_{2} \mathrm{Bu}\right.$, $\left.\mathrm{CH}_{3} \mathrm{Bu}\right) .{ }^{19} \mathrm{~F}$ MAS NMR (376.49 MHz): $\delta-62$ (br). IR $\left(\mathrm{cm}^{-1}\right)$ : $\nu$ (CFst): 1327 (vs.), 1167 (vs.), 1125; $\nu$ (CHסoop): 851.5 (s), 823 (s). The copolymer contains $0.01 \mathrm{mmol} \mathrm{Br}$ per $\mathrm{g}$, which indicates $95 \%$ of Br substitution.

Synthesis of VA-PNBNB $\left(\mathrm{CH}_{2}\right)_{2}-\mathbf{C H}=\mathbf{C H}_{2}$ (20). A mixture of polymer 17 (0.150 g, $0.4006 \mathrm{mmol}), \mathrm{K}^{t} \mathrm{BuO}(0.147 \mathrm{~g}, 1.470$ $\mathrm{mmol}), \mathrm{P}\left({ }^{t} \mathrm{Bu}\right)_{2} \mathrm{Me}(0.0078 \mathrm{~mL}, 0.04 \mathrm{mmol}), \mathrm{Pd}_{2}(\mathrm{dba})_{3}(0.0104 \mathrm{~g}$, $0.01 \mathrm{mmol})$ and 2-methyl-2-butanol $(10 \mathrm{~mL})$ was placed in a Schlenk flask and stirred for $48 \mathrm{~h}$ at $100{ }^{\circ} \mathrm{C}$, under a $\mathrm{N}_{2}$ atmosphere. After this time, the resulting mixture was poured onto $\mathrm{MeOH}(30 \mathrm{~mL})$ and stirred for 30 minutes. The resulting solid was collected by vacuum filtration and washed with $\mathrm{MeOH}$ $(5 \times 5 \mathrm{~mL})$ and air-dried. The polymer was obtained as a greyish solid. Isolated yield: $0.1037 \mathrm{~g}$ (88\%). The copolymer contains 0.05 mmol Br per $\mathrm{g}$, which indicates $99 \%$ of Br substitution. ${ }^{13} \mathrm{C}$ CP-MAS NMR (100.61 MHz): $\delta 140$ (s, 1C, $C \mathrm{H}=\mathrm{CH}_{2}$ ), $116(\mathrm{~s}, 1 \mathrm{C}$, $\left.\mathrm{CH}=\mathrm{CH}_{2}\right), 65-20\left(\mathrm{br}, 9 \mathrm{C}, \mathrm{C}^{1}-\mathrm{C}^{7}, 2 \mathrm{CH}_{2}\right) . \mathrm{IR}\left(\mathrm{cm}^{-1}\right): \nu(\mathrm{C}=\mathrm{Cst})$ :

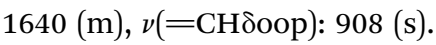

Elimination of residual palladium in the functionalized polymers. To polymer $19(0.0577 \mathrm{~g}, 4.6 \mathrm{mg}$ Pd per g) in dry toluene $(5 \mathrm{~mL})$ was added $N, N$-dimethyl-2-phenyldiazenecarbothioamide $(0.059 \mathrm{~g}, 0.2680 \mathrm{mmol})$. The mixture was refluxed under $\mathrm{N}_{2}$ for $24 \mathrm{~h}$ and, after that time was poured onto $\mathrm{MeOH}(30 \mathrm{~mL})$. The solid was filtered, washed with $\mathrm{MeOH}(5 \times$ $5 \mathrm{~mL}$ ) and dried under vacuum. Isolated yield: $0.0550 \mathrm{~g}$ (93\%). The polymer contained $0.47 \mathrm{mg}$ Pd per $\mathrm{g}$.

\section{Conclusions}

Vinylic addition polynorbornenes (VA-PNBs) with pendant $p$ bromophenyl groups can be synthesized by homopolymerization of $\mathbf{1}$ and copolymerization of $\mathbf{1}$ and norbornene catalyzed by $\left[\mathrm{Ni}\left(\mathrm{C}_{6} \mathrm{~F}_{5}\right)_{2}\left(\mathrm{SbPh}_{3}\right)_{2}\right]$. They are most convenient starting materials for the synthesis of VA-PNBs with aryl, ketoalkyl, alkenyl, and amino functional groups by Pd-catalyzed cross coupling 
reactions, as has been demonstrated in the application of the Suzuki, Stille and Buchwald-Hartwig amination reactions. A successful aryl functionalization by a Suzuki coupling can be applied to the more challenging $\omega$-bromoalkyl-VA-PNB polymer. Post-polymerization functionalization is a very attractive route to synthesize functional VA-PNBs, which are difficult to synthesize by direct polymerization of substituted norbornenes. This opens up new ways to anchor a suitable functionality to the robust and transparent scaffold that the VA-PNB skeleton provides and, thus, increase the range of its applications as a support.

\section{Acknowledgements}

We would like to thank the financial support of the Spanish MINECO (SE I+D+i, grant CTQ2013-48406-P), the MEC (FPU fellowship to JAMT) and the Junta de Castilla y León (grant VA302U13).

\section{Notes and references}

1 (a) R. García-Loma and A. C. Albéniz, RSC Adv., 2015, 5, 70244-70254; (b) M. Eo, D. Han, M. H. Park, M. Hong, Y. Do, S. Yoo and M. H. Lee, Eur. Polym. J., 2014, 51, 37-44.

2 (a) J. H. Park, C. Yun, T.-W. Koh, Y. Do, S. Yoo and M. H. Lee, J. Mater. Chem., 2011, 21, 5422-5429; (b) J. H. Park, C. Yun, M. H. Park, Y. Do, S. Yoo and M. H. Lee, Macromolecules, 2009, 42, 6840-6843.

3 (a) X. He, J. Liu, H. Zhu, Y. Zheng and D. Chen, RSC Adv., 2015, 5, 63215-63225; (b) J.-C. Daigle, V. Dube-Savoie, A. C. Tavares and J. P. Claverie, J. Polym. Sci., Part A: Polym. Chem., 2013, 51, 2669-2676; (c) H. Yao, X. He, L. Chen, Y. Chen and D. J. Chen, Appl. Polym. Sci., 2013, 3540-3547.

4 (a) M. V. Bermeshev, A. V. Syromolotov, M. L. Gringolts, L. E. Starannikova, Y. P. Yampolskii and E. S. Finkelshtein, Macromolecules, 2011, 44, 6637-6640; (b) M. Gringolts, M. Bermeshev, Y. Yampolskii, L. Starannikova, V. Shantarovich and E. Finkelshtein, Macromolecules, 2010, 43, 7165-7172.

5 (a) J. A. M. de la Torre and A. C. Albéniz, ChemCatChem, 2016, 8, 2241-2248; (b) J. A. M. de la Torre and A. C. Albéniz, ChemCatChem, 2014, 6, 3547-3552; (c) I. K. Sagamanova, S. Sayalero, S. Martínez-Arranz, A. C. Albéniz and M. A. Pericàs, Catal. Sci. Technol., 2015, 5, 754-764; (d) N. Carrera, E. Gutiérrez, R. Benavente, M. M. Villavieja, A. C. Albéniz and P. Espinet, Chem.-Eur. J., 2008, 14, 10141-10148; (e) I. Meana, A. C. Albéniz and P. Espinet, Adv. Synth. Catal., 2010, 352, 2887-2891; $(f)$ S. Martínez-Arranz, N. Carrera, A. C. Albéniz, P. Espinet and A. Vidal-Moya, Adv. Synth. Catal., 2012, 354, 3551-3560.

6 Polymers based on the ROMP-hydrogenated polynorbornene are commercialized under the trademark Zeonex® by ZEON corporation. (a) M. Yamazaki, J. Mol. Catal. A: Chem., 2004, 213, 81; (b) J. C. Mol, J. Mol. Catal. A: Chem., 2004, 213, 39.

7 We have developed ROMP-PNBs with haloalkyl groups that can be hydrogenated and lead to robust polymers that can be used, for example, as starting materials for the support of reagents in the Stille reaction. Their performance is comparable to the analogous VA-PNBs, although they need an additional synthetic step for their preparation (see ref. $1 a)$.

8 S. Martínez-Arranz, A. C. Albéniz and P. Espinet, Macromolecules, 2010, 18, 7482-7487 and references therein. 9 (a) F. Pierre, B. Commarieu, A. C. Tavares and J. Claverie, Polymer, 2016, 86, 91-97; (b) B. Commarieu, J. Potier, M. Compaore, S. Dessureault, B. L. Goodall, X. Li and J. Claverie, Macromolecules, 2016, 49, 920-925; (c) P. Hou, W. Liu, X. He, H. Wang and Y. Chen, Organometallics, 2013, 32, 2291-2299; (d) S. V. Mulpuri, J. Shin, B.-G. Shin, A. Greiner and D. Y. Yoon, Polymer, 2011, 52, 4377-4386; (e) K. Müller, Y. Jung, D. Y. Yoon, S. Agarwal and A. Greiner, Macromol. Chem. Phys., 2010, 211, 1595-1601.

10 (a) B. Commarieu and J. P. Claverie, Chem. Sci., 2015, 6, 2172-2181; (b) J. K. Funk, C. E. Andes and A. Sen, Organometallics, 2004, 23, 1680-1683.

11 (a) Nobel Foundation: http://nobelprize.org/nobel_prizes/ chemistry/laureates/2010/press.html; (b) X.-F. Wu, P. Anbarasan, H. Neumann and M. Beller, Angew. Chem., Int. Ed., 2010, 49, 9047-9050.

12 (a) M. Kaur, D. S. Yang, J. Shin, T. W. Lee, K. Choi, M. J. Cho and D. H. Choi, Chem. Commun., 2013, 49, 5495-5497; (b) B. Carsten, F. He, H. J. Son, T. Xu and L. Yu, Chem. Rev., 2011, 111, 1493-1528.

13 (a) R. Molina, S. Gómez-Ruiz, F. Montilla, A. Salinas-Castillo, S. Fernández-Arroyo, M. M. Ramos and R. Mallavia, Macromolecules, 2009, 42, 5471-5477; (b) Y. Tezuka, R. Komiya, Y. Ido and K. Adachi, React. Funct. Polym., 2007, 67, 1233-1242; (c) C. Xue, V. R. R. Donuru and H. Liu, Macromolecules, 2006, 39, 5747-5752; (d) R. Mallavia, F. Montilla, I. Pastor, P. Velásquez, B. Arredondo, A. L. Alvarez and C. R. Mateo, Macromolecules, 2005, 38, 3185-3192; (e) F. Huang, H. B. Wu, D. Wang, W. Yang and Y. Cao, Chem. Mat., 2004, 16, 708-716; (f) U. H. F. Bunz, Chem. Rev., 2000, 100, 16051644.

14 M. Winkler, L. Montero de Espinosa, C. Barner-Kowollik and M. A. R. Meier, Chem. Sci., 2012, 3, 2607-2615.

15 T. Kanbara, K. Izumi, T. Narise and K. Hasegawa, Polym. J., 1998, 30, 66-68.

16 Y. S. Park, Q. Wu, C.-Y. Nam and R. B. Grubbs, Angew. Chem., Int. Ed., 2014, 53, 10691-10695.

17 Pd-catalyzed cross coupling reactions are carried out on polymeric solid supports to synthesize small molecules of interest, followed by their cleavage from the support after the coupling process (solid-phase synthesis). This is a widespread use of these reactions on polymers, but the goal of the process is not the synthesis of a new polymeric material. See for example: S. Bräse, J. H. Kirchhoff and J. Köbberling, Tetrahedron, 2003, 59, 885-939.

18 (a) C. Kub, J. Tolosa, A. J. Zucchero, P. L. McGrier, C. Subramani, A. Khorasani, V. M. Rotello and U. H. F. Bunz, Macromolecules, 2010, 43, 2124-2129; (b) L. B. Sessions, B. R. Cohen and R. B. Grubbs, 
Macromolecules, 2007, 40, 1926-1933; (c) A. B. Morgan and J. M. Tour, Macromolecules, 1998, 31, 2857-2865.

19 (a) F. Bertini, G. Audisio, J. Kiji and M. Fujita, J. Anal. Appl. Pyrolysis, 2003, 68-69, 61-81; (b) E. B. Stephens and J. M. Tour, Macromolecules, 1993, 26, 2420-2427.

20 E. Schwartz, K. Breitenkamp and V. V. Fokin, Macromolecules, 2011, 44, 4735-4741.

21 Y. Li, G. Vamvounis, J. Yu and S. Holdcroft, Macromolecules, 2001, 34, 3130-3132.

22 (a) T. Kanbara, Y. Yokokawa and K. Hasegawa, J. Polym. Sci., Part A: Polym. Chem., 2000, 38, 28-34; (b) T. Kanbara, M. Oshima and K. Hasegawa, J. Polym. Sci., Part A: Polym. Chem., 1998, 36, 2155-2160.

23 L. Carvalho, M. Dias Pires, E. Fernandes and M. Marques, RSC Adv., 2013, 3, 25711-25715.

24 (a) J. A. Casares, P. Espinet, J. M. Martín-Alvarez, J. M. Martínez-Ilarduya and G. Salas, Eur. J. Inorg. Chem., 2005, 3825-3831.

25 The composition data of the copolymers $(F)$ obtained for the copolymerization at different monomer feed ratios $(f)$ were fitted to the Finemann-Ross equation: J. M. G. Cowie, Polymers: Chemistry \& Physics of Modern Materials, Chapman \& Hall, Cheltenham, 1991.

26 (a) W. Kaminsky, A. Bark and M. Arndt, Makromol. Chem., Macromol. Symp., 1991, 41, 83-93; (b) M. Arndt, R. Engehausen, W. Kaminsky and K. Zoumis, J. Mol. Catal. A: Chem., 1995, 101, 171-178.

27 (a) D. A. Barnes, G. M. Benedikt, B. L. Goodall, S. S. Huang, H. A. Kalamarides, S. Lenhard, L. H. McIntosh, K. T. Selvy, R. A. Shick and L. F. Rhodes, Macromolecules, 2003, 36, 2623-2632.

28 Some references with mechanistic information: (a) Metal Catalyzed Cross-Coupling Reactions, ed. A. Meijere and F. Diederich, Wiley-VCH, Weinheim, 2004. Stille reaction: $(b)$ J. K. Stille, Angew. Chem., Int. Ed. Engl., 1986, 25, 508-524; (c) C. Cordovilla and C. Bartolomé, ACS Catal., 2015, 5, 3040-3053. Suzuki reaction: (d) C. Amatore, G. Le Duc and A. Jutand, Chem.-Eur. J., 2013, 19, 10082-10093. Amination: (e) J. F. Hartwig, Angew. Chem., Int. Ed., 1998, 37, 2046-2067.

29 (a) Z. Lu and G. C. Fu, Angew. Chem., Int. Ed., 2010, 49, 66766678; (b) J. H. Kirchhoff, M. R. Netherton, I. D. Hills and G. C. Fu, J. Am. Chem. Soc., 2002, 124, 13662-13663; (c) J. H. Kirchhoff, C. Dai and G. C. Fu, Angew. Chem., Int. Ed., 2002, 41, 1945-1947; (d) M. R. Netherton, C. Dai, K. Neuschütz and G. C. Fu, J. Am. Chem. Soc., 2001, 123, 10099-10100.

30 K. T. Nielsen, K. Bechgaard and C. Krebs, Macromolecules, 2005, 38, 658-659.

31 (a) A. Arcas and P. Royo, Inorg. Chim. Acta, 1978, 30, 205-207; (b) G. Lopez, G. García, G. Sánchez, J. García, J. Ruiz, J. A. Hermoso, A. Vegas and M. Martínez-Ripoll, Inorg. Chem., 1992, 31, 1518-1523.

32 T. Hayashi, M. Konishi, Y. Kobori, K. Hirotsuf, M. Kumada and T. Higuchi, J. Am. Chem. Soc., 1984, 106, 158-163.

33 D. R. Coulson, L. C. Satek and S. O. Grim, Inorg. Synth., 1990, 28, 107-109.

34 J. Chatt and F. G. Mann, J. Chem. Soc., 1939, 1622-1634.

35 T. Ukai, H. Kawazura, Y. Ishii, J. J. Bonnet and J. A. Ibers, J. Organomet. Chem., 1974, 65, 253-266.

36 H. A. Tayim, A. Bouldoukian and F. J. Awad, J. Inorg. Nucl. Chem., 1970, 32, 3799-3803.

37 A. L. Casado and P. Espinet, J. Am. Chem. Soc., 1998, 120, 8978-8985.

38 D. C. White, Microchim. Acta, 1961, 49, 449-456.

39 Norbornene is a waxy solid, which sublimes easily. In order to accurately measure small quantities of this monomer, we used solutions of $\mathrm{NB}$ in $\mathrm{CH}_{2} \mathrm{Cl}_{2}$, previously titrated by ${ }^{1} \mathrm{H}$ NMR. 